Review

\title{
Classification of Measures for Dealing with District Heating Load Variations-A Systematic Review
}

\author{
Danica Djurić Ilić $\mathbb{C}$
}

Division of Energy Systems, Department of Management and Engineering, Linköping University, 58183 Linköping, Sweden; danica.djuric.ilic@liu.se

\begin{abstract}
The highly varying character of district heating (DH) demand results in low capacity utilization of the DH plants, as well as increased use of fossil fuels during peak demand. The aim of this study is to present an overview and a comprehensive classification of measures intended to manage these load variations. A systematic literature review was conducted based on previously defined search strings as well as inclusion and exclusion criteria. Two scientific databases were used as data sources. Based on 96 detected publications, the measures were categorized as (1) complementing $\mathrm{DH}$ production in heat-only boilers (HOBs), or geothermal or booster heat pumps (HPs) (usually controlled by the DH company), (2) thermal energy (TE) storage in storage units or in the network (controlled by the company), and (3) demand side measures, which can be strategic demand increase, direct demand response (DR), or indirect DR. While the company has control over direct DR (e.g., thermal storage in the thermal mass of the buildings), indirect DR is based on communication between the customer and the company, where the customer has complete control. The multi-disciplinary nature of this topic requires an interdisciplinary approach.
\end{abstract}

Keywords: district heating; load management; demand side measures; demand response

Citation: Djurić Ilić, D. Classification of Measures for Dealing with District Heating Load Variations-A Systematic Review. Energies 2021, 14, 3. https://doi.org/10.3390/en1401 0003

Received: 26 November 2020 Accepted: 17 December 2020 Published: 22 December 2020

Publisher's Note: MDPI stays neutral with regard to jurisdictional clai$\mathrm{ms}$ in published maps and institutional affiliations.

Copyright: $\odot 2020$ by the author. Licensee MDPI, Basel, Switzerland. This article is an open access article distributed under the terms and conditions of the Creative Commons Attribution (CC BY) license (https:// creativecommons.org/licenses/by/ $4.0 /)$.

\section{Introduction}

Utilization of demand side measures and load management measures has historically (since the 1980s) been associated with the electricity sector [1]. The measures have mostly focused on achieving desired changes in the load shape that would result in improved energy utilization and system economic performance. Interest in the subject has increased even more over the last two decades due to the interest in increasing the proportion of intermittent electricity production (wind and solar power); this is associated with several challenges including the uncertainties regarding wind forecasts and cloud movements. This challenge moved the focus from energy- to power-related problems, i.e., matching electricity demand with production at any given time. Two possible strategies to overcome this challenge are: to build a reserve capacity into the electricity grid or to develop flexibility on the demand side of the system [2,3]. Historically, the interest in demand side management (DSM) and load management has not been as high for district heating (DH) as for the electricity sector, because optimization of DH systems (DHSs) has usually focused on the issues associated with the production and distribution sides of the system.

$\mathrm{DH}$ technology has a strong potential for becoming a vital part of the future energy systems [4-8]. The fundamental idea of DH is to use local fuels and heat resources, which otherwise would be wasted (e.g., excess heat from industrial processes, waste incineration, thermal power stations, and electricity users) [9]. When considering the large share of the heat losses in the existing energy systems (e.g., approximately two-thirds of the total primary energy used in the European Union (EU) [10]), it can be concluded that DH has a potential to contribute to a substantial reduction of the global primary energy use. Besides the benefits that are directly related to this fundamental idea (e.g., security of supply, flexibility, and economy of scope), two other benefits of DH technology are economy 
of size (some technologies have lower costs and/or higher energy efficiency at higher production volumes) [9], and possibility to contribute to the sustainable development of other sectors $[5,7,8]$. The $\mathrm{DH}$ sector can support the development of the future sustainable energy system by reducing fossil fuel consumption (1) in the industry sector by conversion of industrial processes from fossil fuels to DH use [11-13], (2) in the transport sector by integrating renewable transport fuels production in DHSs (e.g., biogas, ethanol, FischerTropsch diesel) [14,15], and (3) in the power sector by producing electricity in biomassor waste-fueled combined heat and power (CHP) plants [16-18]. The DH sector can also enable an increased share of intermittent electricity sources in the power sector by serving as a flexible electricity producer (CHP) and user (heat pumps (HPs) and electric boilers) $[19,20]$. Even though many researchers pointed out these potentials and benefits, the global awareness of them is still low [4]. The DH implementation globally is low, and it varies from country to country, as well as the commitment to the fundamental idea of $\mathrm{DH}[4]$.

However, in order to utilize the full potential of $\mathrm{DH}$ it is necessary to adapt the existing DHSs to buildings with low heat demands [21,22], and to the renewable energy sources. Possibility to use the renewable energy sources for the DH production (solar collectors, geothermal heat resources and biofuels) is associated to local conditions. Furthermore, the renewable energy sources are usually related to other challenges as well. The solar $\mathrm{DH}$ is still in the development stage. Using solar collectors for $\mathrm{DH}$ production requires large areas and investments in seasonal thermal energy (TE) storages [9]. Although the biofuel-based DH production is a well-developed technology, and the biofuels are suitable within the traditional DH production infrastructure established for utilization of fossil fuels, the biofuel is still a limited resource, so it cannot substitute all current fossil fuel use [4].

Another challenge related to the existing DHSs is the highly varying character of $\mathrm{DH}$ demand, which results in low capacity-utilization of the existing DH plants and, consequently, to a lower interest to invest in DH plants that are characterized by high investment costs, such as biomass- or waste-fueled CHP plants and heat-only boilers (HOB). Therefore, biomass- or waste-fueled CHP plants usually serve only base DH production, while the rest of the $\mathrm{DH}$ is usually produced by biomass-fueled HOB. The HOB used during peak demands are usually fossil-fuel $\mathrm{HOB}$, which are characterized by high operating costs such as oil-fired HOB in Sweden [23] and natural gas-fired boilers in Germany [24]. Thus, peak demands are not only associated with higher $\mathrm{DH}$ production costs, but also with increased greenhouse gas emissions.

Another disadvantage of DH peak demands is the lower technical performance of the system. If the DH load control is based on mass flow variation (explained later in Section 2.2), peak demands result in high pumping costs, an increased risk of failure due to the increased mass flow through the existing bottlenecks, and the occurrence of new bottlenecks [25]. Namely, all pipes in a DH network are dimensioned for a certain flow. When the DH demand increase, the mass flow through the network increase as well (explained in Section 2.2). If the flow through a DH pipe increase above the flow value for which the pipe is dimensioned, this may cause too high pressure loss, and consequently insufficient differential pressure in the $\mathrm{DH}$ area attached to the pipe. This in turn leads to a problem to sufficiently deliver heat to the DH customers located in this DH area [26]. In this paper, the term bottleneck is used to refer to the DH pipe which have too small dimension to enable a sufficient $\mathrm{DH}$ delivery to the $\mathrm{DH}$ area attached to it. Besides during the DH peak demands, the problems with bottlenecks may occur when expanding the $\mathrm{DH}$ network (the pipe's dimension can become too small when connecting more DH customers) and when reducing the DH supply temperature. Historically, the bottleneck problems have often been addressed by increasing the DH supply temperature before an expected demand increase in the attached DH area (explained more in Section 2.2), by exchanging the pipe with a pipe with a larger dimension, by installing an extra pipe, by raising the differential pressure in the attached $\mathrm{DH}$ area with extra pumps, and by installing decentralized $\mathrm{DH}$ 
production plants in the affected DH area. Some relatively new strategies for dealing with the bottleneck problems are DSM and investments in thermal energy storage (TES) units [26].

The above mentioned problems have increased the interest to manage DH load variations in more efficient, environmental friendly, and profitable ways. One example of the possible strategies is increasing flexibility on the demand side of the DHS. Increased flexibility on the demand side of the DHS would be beneficial for managing the peak demands while also facilitating increased capacity and renewable energy utilization [27]. This would enable connection of new DH customers without modification of the existing pipelines [28], and would decrease the mass flow rate through the network bottlenecks [26]. Increased flexibility on the demand side of the DHS would also enable better interaction between the electricity and $\mathrm{DH}$ sectors by increasing the CHP electricity production in DHS [29-31].

\subsection{Aim}

The aim of this study is to provide an overview of the existing measures for managing DH load variations by categorizing them depending on (1) the part of the system to which the measures are applied; (2) the driving stakeholders; (3) the timeframe in which the measures contribute to reduction of the DH load variation (optimized schedule, temporary or permanent); and (4) the type of variations that are affected (seasonal or daily). Furthermore, the measures are discussed from energy efficiency, economic, and environmental viewpoints.

This paper is structured as follows. Section 1 describes the problem and aim; Section 2 presents the theoretical background of the study; Section 3 describes the systematic literature review that was conducted; Section 4 presents the results; and Section 5 includes interpretation of the results and a discussion on the study's limitations, as well as recommendations for future research. Section 6 presents the conclusion.

\section{Theoretical Background}

\subsection{Characteristic of Heat Loads in a DHS}

An aggregate heat load in a DHS usually consists of different types of heat loads (e.g., heat loads related to space heating, hot-tap water preparation, DH-driven absorption cooling and heat use in industrial processes), and as a result is characterized by different types of variation: seasonal (consequences of variations in outdoor temperature), daily (mostly originating in the customer's behavior), and variations due to weather dependence [9]. The connected customers can have different DH load patterns depending on control strategy, season, customer category (e.g., multi-dwelling buildings, administration building), and indoor activities [32]. The customer's behavior causes daily DH peak demands mostly in the morning and evening due to hot-tap water use. To even out these daily variations, heat storage units with small capacities are sufficient. On the other hand, the seasonal DH variations can be $30 \%$ compared to the annual average $\mathrm{DH}$ load demand, and therefore require large-scaled TES [33].

\subsection{Managing a $D H S$}

Managing a DHS requires good insight in the diversity of individual DH load patterns in the network, design heat load (i.e., the capacity demand which must be fulfilled), challenges related to the DH network (e.g., existing of bottlenecks), and capacity utilization. Capacity utilization (also called capacity factor, load factor, or utilization time) is the degree to which the installed capacity can be utilized for heat supply, and depends on the aggregate heat load variation in the DHS. High capacity utilization results in lower production costs [9].

The DH control system consists of four independent systems. Two are operated by the heat provider (supply temperature control and differential pressure control), one is located within the customers' heating systems (heat demand control), and one is located in 
the DH substations (control of the flow through the pipes on the primary sides of the heat exchangers in the DH substations) [9]. The heat demand control consists of manual taps and radiator thermostatic valves (mechanical self-acting or motorized valves, which regulate the flow rate through the radiator). The way in which the flow in the substation is controlled may differ. A DH substation may be owned by the DH customer (e.g., building owner), by the DH provider, or the ownership may be shared. Since international standardizations related to the $\mathrm{DH}$ substations are progressing slowly, traditional practices at the national level play a significant role for the technical, and organizational aspects. The flow control in the DH substation usually consists of two valves (located on the primary sides of the heat exchangers in the DH substations), one for the radiator system and one for the domestic hot-tap water [9].

When the DH demand increases, the DH providers usually respond by increasing the supply temperature. However, this change in the network propagates slowly. It takes approximately $1.5 \mathrm{~h}$ for this change to reach a $\mathrm{DH}$ substation that is located $10 \mathrm{~km}$ from the $\mathrm{DH}$ production plant. If the increased supply temperature does not reach the substation in time to cover the increased DH demand, the flow control in the substation will increase the mass flow through the pipes. This change can be transferred at about one kilometer per second, and may result in the increased mass flow through the network's bottlenecks between the DH production plants and the customer [26] (the concept of bottlenecks is explained in Section 1), as well as in a higher return temperature and, consequently, in higher heat losses in the network, as well as a lower energy efficiency of the DH production plants [9]. This undesirable situation can be prevented if the DH providers increase the supply temperature manually in advance. In order to do this, it is important to provide short-term heat load forecasting, and therefore it is necessary to have good insight in daily heat load variations. This challenge has been addressed in a number of studies [32,34-41]. Short-term heat load forecasting is also important for CHP electricity generation forecasts, because in order to balance supply, the electricity generation must be reported the day before the electricity is delivered into the electricity network.

Another issue which must be considered when managing a DHS is that most DH customers are able to accommodate more heat than their design heat power. The reason is that when installing the components in the customer's heating system and substation, a component size one dimension greater than that necessary for the design heat power is always chosen. For example, the radiators are often oversized [42,43]. Moreover, as previously explained, the customer can influence the heat transfer in the substation and the heat demand (e.g., the radiator thermostatic valves). Consequently, when there is a deficit in the DH supply, the heat deliveries cannot be shared equally to all customers in the DHS. The customers located near the supply units will draw all the heat that they need to meet their demand, while the system's entire heat deficit will be distributed to the customers at the periphery of the network [9].

This can be avoided by providing the DH providers with the option of direct load control in the substations. By taking control over the substations, the DH providers will get an opportunity to more equally allocate the supply deficiency. This can be achieved by installing flow limiters in the substations (a local solution that would also reduce the return temperature in the DHS [44]) or by installing a central load management unit capable of communicating with all substations in the system (similar to that described by Wernstedt [45]).

\section{Methods}

The method used in this paper is a systematic review, in combination with two types of traditional reviews (scoping and conceptual). The main differences between a traditional review and a systematic review is in the design and the methodological approach. The systematic review is a structured method based on a protocol which must be presented in detail (e.g., the search strings, the applied inclusion and exclusion criteria) for transparency, so that the results can be reproduced if the research is repeated under the 
same conditions. This helps to reduce bias, i.e., the author's preconceptions. This makes the systematic review a particularly useful method for development of policy measures. In general, a systematic review usually aims to locate relevant studies based on a prior formulated research question, to evaluate and synthesize their respective contributions, to provide an historical perspective of interest for the topic, and to identify the knowledge gap in order to highlight subjects which require more attention [46].

Traditional reviews are comprehensive reviews that allow a certain flexibility and open the possibility to explore ideas. According to Jesson et al. [47], depending on the purpose of the review, there are five types of traditional reviews: critical, conceptual, state-of-art, expert, and scoping reviews. Two types of traditional review are included in this study: a conceptual and a scoping review.

A scoping review usually aims to gain a broad understanding of an issue, and it is therefore appropriate when wishing to point the way to future research by refining the research questions, concepts and theories. It is usually used as the first step when conducting a systematic review [47]. According to Arksey and O'Malley [48], a key strength of the scoping review is that it can conduct mapping of areas of research, summarize research findings, and identify the knowledge gaps in a shorter time than a systematic review.

The aim of a conceptual review is to gain a deeper and more complex understanding (conceptual knowledge) of an issue, i.e., to understand principles, theories, conceptual relationships, patterns, classifications, and possibilities for generalization. Therefore, conducting a conceptual review can be an engaging and challenging process. In practice, achieving a conceptual understanding will enable transfer of an idea and its application in other contexts and across domains $[46,48]$.

\section{Conducting the Systematic Review}

The systematic review was conducted using six phases as described by Jesson et al. [46].

Phase 1: the scoping review was conducted to determine the current state of knowledge on the topic, and to set the scene for the systematic review. This was achieved by refining the research question, compiling the search strings, and defining the inclusion and exclusion criteria that were to be applied during the systematic review. The search strings and inclusion and exclusion criteria applied for the systematic review are presented in Table 1. Phase 2: when conducting a systematic review, Jesson et al. [46] recommends limiting the search only to peer-reviewed scientific journal articles. However, the aim of this research is to detect more potential strategies for dealing with $\mathrm{DH}$ load variation. Therefore, conference proceedings were also included in the search. After searching through the scientific databases and excluding any duplicates, each title and abstract was screened, and for some articles, the full text was scanned.

Phase 3: all articles were screened and assessed for quality. This is recommended in a systematic review, even though the assessment involves a degree of subjectivity [46]. An additional quality assessment of the conference papers was performed. This assessment was based not only on the relevance and quality of the article, but also on the author's competence by examining the author's previous publications in this area of research. While assessing the articles, additional scientific studies were detected through manual screening of cross-references.

Phases 4 and 5: in order to prepare the interpretative framework for data extraction and synthesis, a conceptual review was conducted. The conceptual review aimed to gain knowledge on concepts and principles related to the strategies for dealing with electricity load variations, but above all, on possible ways to categorize these strategies. This conceptual knowledge was used as a starting point for formatting the interpretative framework for processing, analyzing, and categorizing the strategies for dealing with the DH load variations.

The conceptual review was conducted by searching through the Web of Science database, using search string: ('classification' OR 'categorization' OR 'categorisation') AND ('demand side management' OR 'demand-side management' OR 'demand man- 
agement' OR 'load management') AND ('power system' OR 'electricity system'). One of the challenges when preparing the interpretative framework was that the articles detected during the conceptual review used a confusing range of terminologies. Terms that were commonly used sometimes had different meanings, and a lack of common classification of the strategies was detected. This presented a problem when comparing the classifications proposed in these articles, and when establishing relationships between several terms. The interpretative framework that was proposed based on the acquired conceptual knowledge (Figure 1) allowed identification of characteristics and patterns of information, and to establish relationships between them, which was also useful in creating research statements.

Table 1. The search strings and inclusion and exclusion criteria applied for the systematic review.

\begin{tabular}{|c|c|}
\hline \multicolumn{2}{|r|}{ Systematic Review } \\
\hline Search Database & Online Scientific Databases Web of Science and Scopus \\
\hline Search string & $\begin{array}{c}\text { ('demand side management' OR 'demand-side management' OR 'demand management' } \\
\text { OR ‘load management' OR ‘demand-shifting' OR ‘load-shifting' OR 'peak load reduction' } \\
\text { OR ‘peak-load reduction' OR 'peak shaving' OR 'peak-shaving' OR ‘seasonal demand } \\
\text { variation' OR ‘seasonal DH demand variation' OR 'seasonal district heating demand } \\
\text { variation' OR ‘seasonal load variation' OR ‘seasonal DH load variation' OR ‘seasonal } \\
\text { district heating load variation' OR 'seasonal variation') } \\
\text { AND } \\
\text { ('district heating') }\end{array}$ \\
\hline Search domains for the search string & TOPIC, ABSTRACT, TITLE/ABSTRACT/KEYWORDS \\
\hline Document type & Original and review journal articles and peer-reviewed conference papers \\
\hline Language & English \\
\hline Availability & Available online as full text \\
\hline Timespan & 1975-July 2020 \\
\hline
\end{tabular}

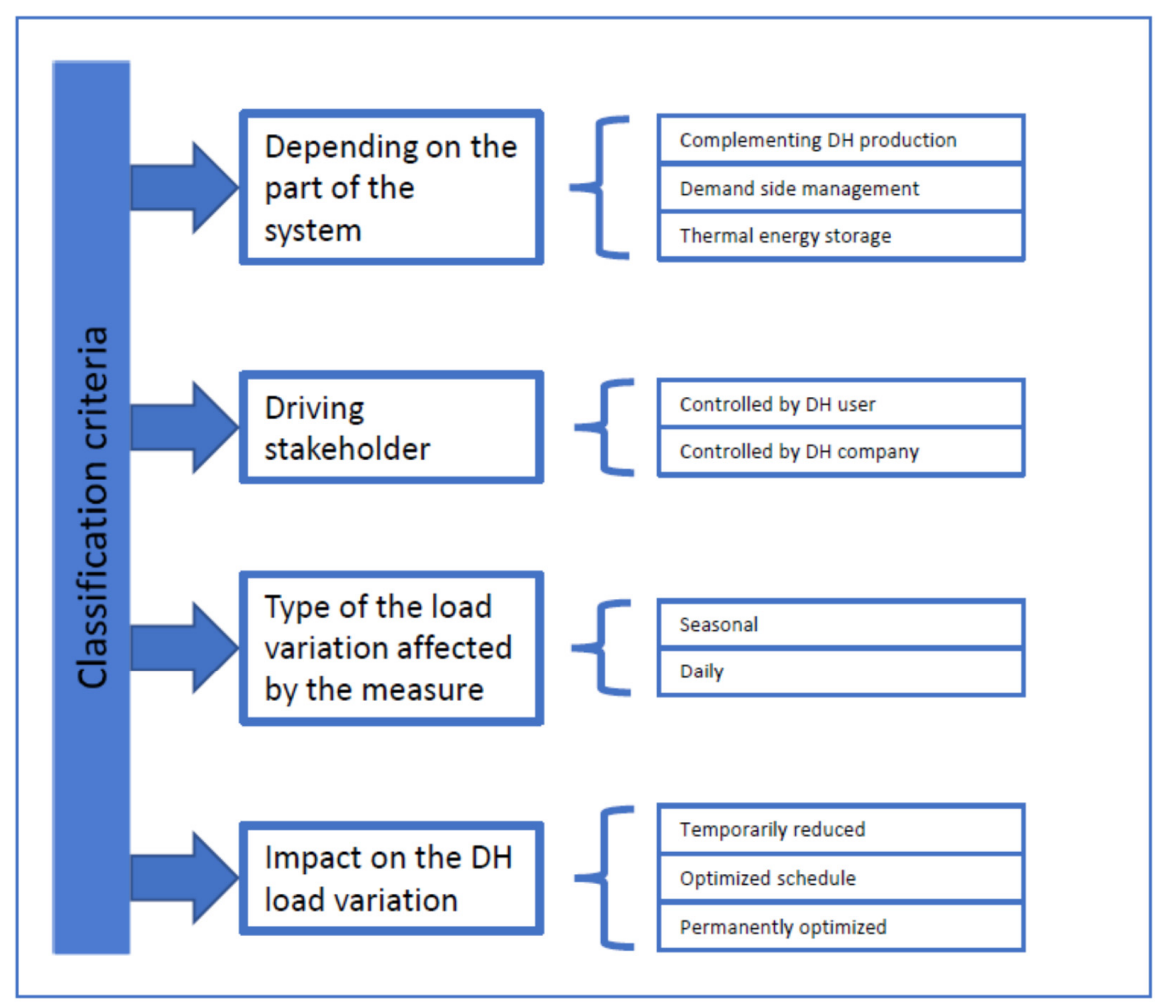

Figure 1. The interpretative framework. 
Phase 6: finally, the strategies were gathered in different categories using a comparative style, and the results were summarized in a meaningful way.

\section{Results}

The results from the scoping review, performed to determine the current state of knowledge on the topic and to set the scene for the systematic review, revealed a lack of general descriptions of load management and DSM, as well as a lack of classification of the strategies. On the other hand, several articles that dealt with these issues relating to the electricity sector have been found. This finding was used as a starting point for developing the aim of this study (see Section 1.1).

After conducting the comprehensive search and quality assessment of the articles, and inclusion of the cross-references, 96 articles were detected as relevant for this study (Figure 2). A large proportion of the detected articles were published during the last five years, which shows that interest in the demand side and load management related to the DH sector is increasing, especially for short-term heat storage in the thermal mass of buildings (Table 2). Furthermore, a majority of the detected studies are case studies limited to presenting one or two types of measures.

One of the classification criteria applied in this study is based on the part of the system to which the measure is applied (Figure 1). Basically, the load management measures related to the $\mathrm{DH}$ sector can be applied to the supply (production) side or to the demand side of the system. However, one of the strategies detected during the literature review, TES, was difficult to classify in any category; this will be discussed in the following text. A general categorization proposed in this study is presented in Figure 3.

Table 2. A list of the publications per measure. Some of the studies include more than one measure.

\begin{tabular}{|c|c|c|c|c|c|}
\hline Time Period & 2016-2020 & 2011-2015 & 2001-2005 & 1990s and 1980s & References \\
\hline \multicolumn{6}{|c|}{ Complementing district heating (DH) Production } \\
\hline $\begin{array}{l}\text { Centrally located } \\
\text { peak-shaving } \\
\text { (peak-load) boilers }\end{array}$ & 1 & 1 & & & {$[49,50]$} \\
\hline \multicolumn{6}{|c|}{ Distributed Peak-Shaving Sources Connected to the Primary or Secondary Network } \\
\hline Peak-shaving boilers & 3 & 1 & & & [50-53] \\
\hline $\begin{array}{l}\text { Peak-shaving geothermal } \\
\text { heat pumps (HPs) }\end{array}$ & 1 & & & & [54] \\
\hline Peak-shaving booster HPs & 7 & & & & [55-61] \\
\hline \multicolumn{6}{|c|}{ Strategic Demand Increase } \\
\hline $\begin{array}{l}\text { Increasing the base DH } \\
\text { load demand }\end{array}$ & & 1 & 1 & & {$[11,12]$} \\
\hline Valley-filling & 1 & 3 & 5 & & {$[12,13,62-68]$} \\
\hline \multicolumn{6}{|c|}{ Demand Response (DR) } \\
\hline Direct & 30 & 2 & 1 & & {$[25,27,30,31,39,54,69-95]$} \\
\hline Indirect & 8 & 1 & 1 & & {$[27,30,76,83,96-101]$} \\
\hline \multicolumn{6}{|c|}{ Thermal Energy (TE) Storage } \\
\hline $\begin{array}{l}\text { Long-term Thermal } \\
\text { Energy Storage (TES) }\end{array}$ & 13 & 3 & & & [102-117] \\
\hline \multicolumn{6}{|c|}{ Short-Term TE Storage } \\
\hline Centralized short-term TES & 10 & 1 & 3 & & [31,102-104,106,117-125] \\
\hline $\begin{array}{c}\text { Decentralized (distributed) } \\
\text { short-term TES }\end{array}$ & 9 & 5 & & 1 & {$[9,26,31,123-134]$} \\
\hline
\end{tabular}




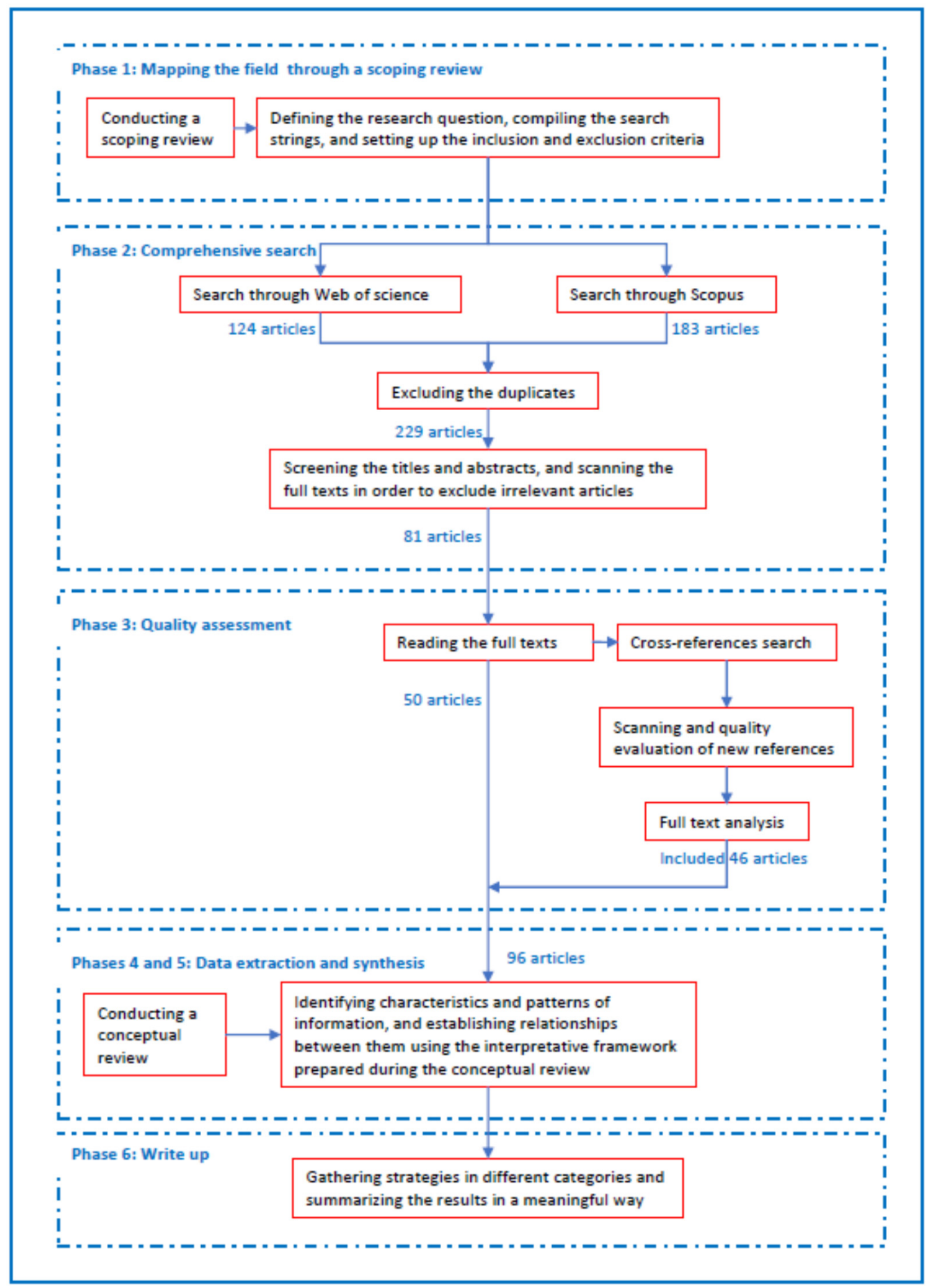

Figure 2. The flow diagram for the conducted systematic review.

According to Fang et al. [49], there are two strategies that can be used on the DH production side to deal with $\mathrm{DH}$ load variation: (1) discarding heat by using cooling towers, or (2) heat production in complementing heat production sources (which is a strategy corresponding to 'complementing generation', one of the functionality-based categories of electric load management described by Göransson and Johnsson [135]). The complementing heat production sources that manage the DH peak loads are called 'peakshaving' or 'peak load' DH sources. In combination with an automatic control system, and if capable of changing their production mode quickly enough, these 'peak-shaving' sources can serve as typical 'spinning reserves' for DHSs (comparable to the 'spinning reserves' for dealing with electricity load variation described by Palensky and Dietrich [136]). 


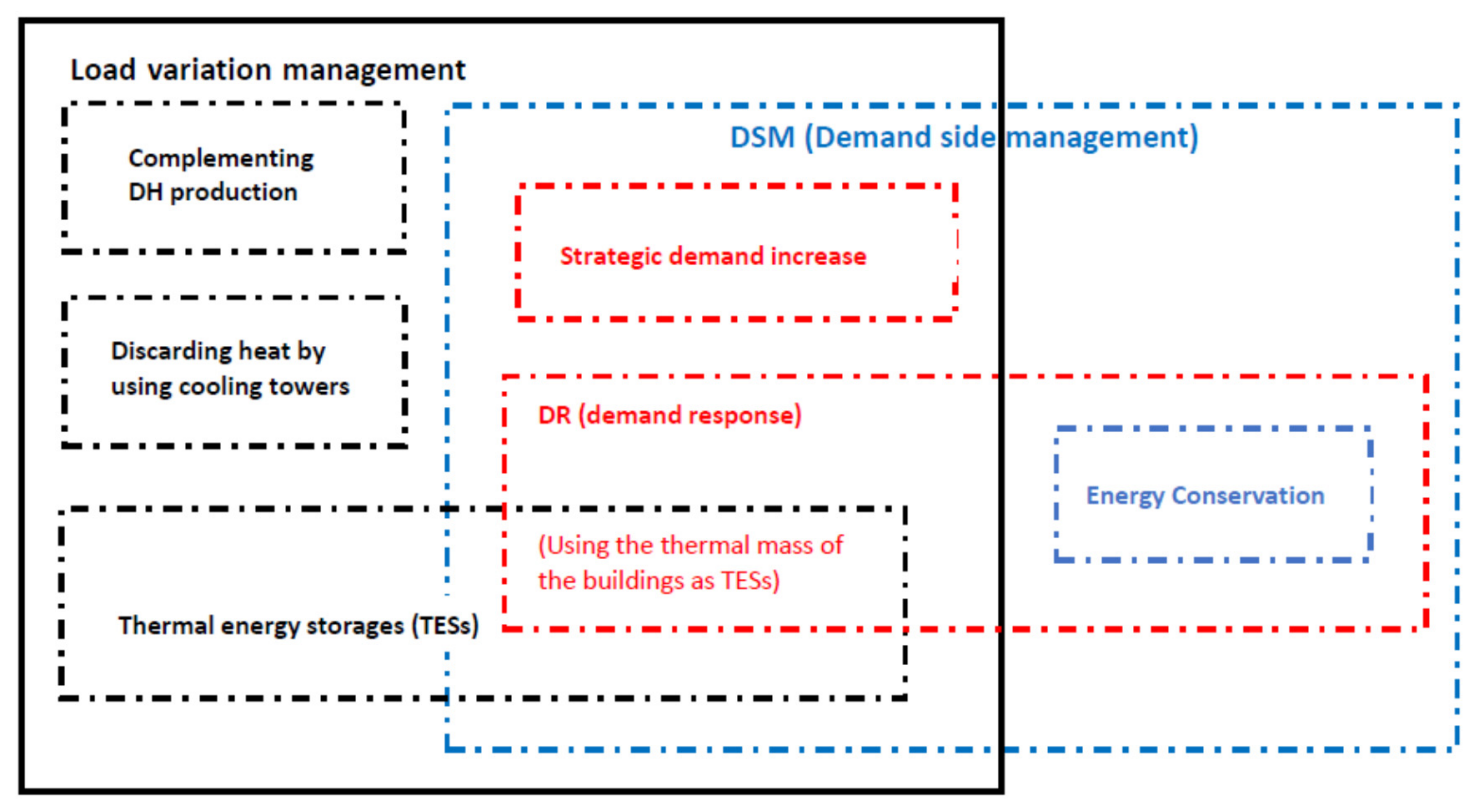

Figure 3. The proposed general categorization of the DH load management measures.

In addition to discarding heat and utilizing complementing heat production sources, TE storage is one of the major solutions for load management in DHSs. Utilization of TES systems enables optimization of $\mathrm{DH}$ production schedules by increasing $\mathrm{DH}$ production when $\mathrm{DH}$ demand is low (i.e., when marginal DH production is characterized by low operational costs), and by reducing DH production in peak-load plants with high operational costs when $\mathrm{DH}$ demand is high. Shifting the $\mathrm{DH}$ demand to the periods when the marginal DH production is in the CHP plants, can lead to additional economic benefits due to increased income from the sale of electricity [29]. This measure can also lead to significant primary energy savings (from a global perspective) if the alternative to the CHP production is the separate production of heat in HOBs and power in a thermal power plants [29]. Other purposes of TES are to provide rapid heat reserves to avoid losses that are associated with quick starts and stops of the $\mathrm{DH}$ plants, or to provide heat reserves during periods when the network cannot deliver enough heat due to the existing bottlenecks between the production plants and the customers. As previously mentioned, it is difficult to categorize this strategy in the category for measures applied on the supply (production) side or on the demand side of the system. The reason is that the heat can be stored in centralized short-term TESs located close to CHP plants; incorporated in CHP installations; in small buffer tanks located close to end users; in the DH network; or even in the thermal mass of the buildings connected to the network. Thus, TES is proposed as a separate category which partly overlaps with the demand side category (Figure 3) because storing heat in the thermal mass of the connected buildings can clearly be categorized as a demand side measure.

Measures applied to the demand side of the system are called DSM measures. Fattahi Meyabadi and Deihimi [1], Lampropoulos et al. [137], and Palensky and Dietrich [136], highlighted the topics of the DSM and load variation management from the electricity system operator's viewpoint, and proposed a comprehensive classification of these measures. According to them, DSM is broader in scope than load management. The reason is that DSM includes all measures that are applied to the demand side of a system, including energy conservation measures. However, energy conservation measures are not included in this study as the study focuses on the measures for dealing with load variation in DHSs. Furthermore, since these measures can be applied to both the demand and supply side of the DHSs, DSM is only one category in the proposed categorization of load variation management (Figure 3). This categorization is more similar to that presented by Görnsson and Johnsson [135], who included 'complementing generation' as a category for electricity 
load variation management, and to Benetti et al. [138], who focused only on DSM that changes the load profile in the system.

The categorization presented by Lampropoulos et al. [137] was adapted for further categorization of the load management related demand side. Accordingly, the proposed categorization (Figure 3), for DSM includes (1) strategic demand increase which implies finding new ways for DH utilization, and (2) demand response (DR) measures which are applied to the existing DH demand. Both types of measures focus on achieving desirable changes of the DH load profile to optimize the entire system, i.e., on increasing the load factor of the DHS (DR by peak-clipping, strategic conservation, and load shifting, with strategic demand increase by increasing the base load and valley filling). The load variation management categories presented in Figure 3 are further divided into sub-categories and presented in the following sections.

\subsection{Complementing DH Production and 'Peak Shaving' DH Sources}

A categorization of the complementing DH production sources is presented in Figure 4. The type of 'peak-shaving' DH plants in DHSs differs from country-to-country, mostly due to the fuel market conditions. For example, while the common 'peak-shaving' plants in China are coal-fired boilers [50], in Sweden 'peak-shaving' plants are oil-fired, and in Germany gas-fired boilers are utilized for this purpose [139]. The 'peak-shaving' ('peak load') heat boilers are usually characterized by low investment costs and flexible adjustment, but by high operation costs. Additionally, one of the ways to deal with the DH demand variation is for $\mathrm{DH}$ producers to refrain from a part of $\mathrm{CHP}$ electricity production in order to produce more $\mathrm{DH}$ in their $\mathrm{CHP}$ plants when the demand increases.

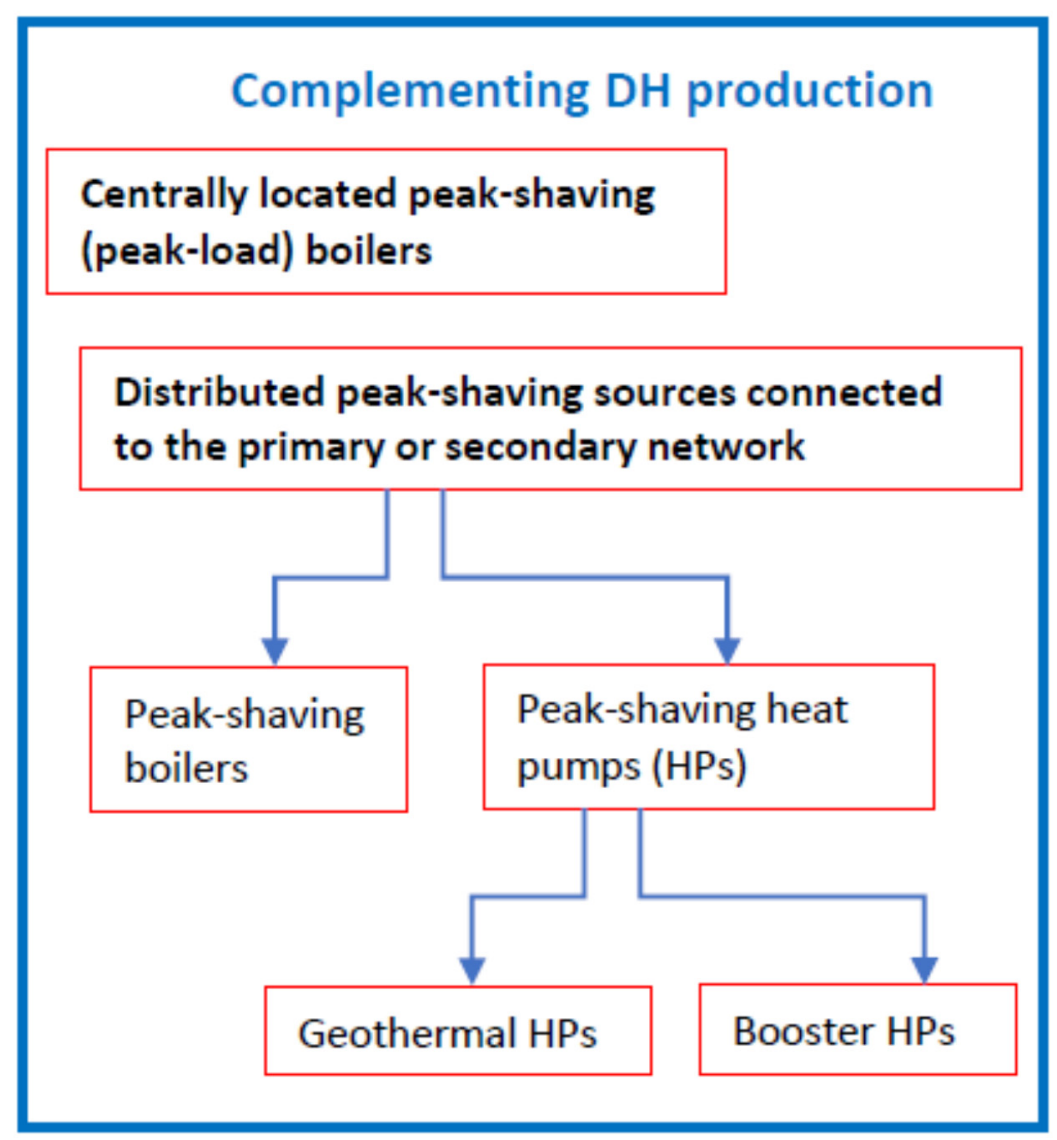

Figure 4. Proposed categorization of the complementing DH production sources that manage DH load variations.

The 'peak-shaving' sources can be centralized (usually one heat source connected to the primary network, i.e., the network on the primary sides of the heat exchangers in 
the thermal substations) or decentralized, i.e., distributed (several DH sources connected in series or in parallel to the primary or secondary DH network) $[50,53,61])$. While some researchers, who studied DHSs where industrial waste heat or coal-fired CHP plants serve as base-load DH sources, recommended gas-fired boilers as 'peak-shaving' sources in these DHSs [49-52], other researchers proposed utilization of HPs as an alternative [54,60,61].

Utilization of decentralized (distributed) gas-fired boilers in a coal-fired CHP-based DHS would result in increased system energy efficiency, as well as providing environmental and economic benefits, compared to coal heating alone [52]. For instance, the gas-fired 'peak-shaving' boilers located in DH substations can provide approximately $50 \%$ of the $\mathrm{DH}$ load on the coldest days in North China [51]. These small boilers can be adjusted more quickly than a conventional centralized 'peak-shaving' boiler, and specifically according to the end users connected to the substation; e.g., special temperature requirements can be met for hospitals and nursing homes, or heat production by the boilers can be suspended for schools during holidays [51]. However, in order to have the option to adjust DH production specifically according to the end users, a management system mode that enables DH producers to apply this strategy is required [51]. The only situation in which it is advantageous to build the 'peak-shaving' boilers centrally (compared to decentralized boilers) is when there is a possibility for 'self-use' of the electricity produced in the system's CHP plant. In this case, the 'peak-shaving' boiler should be located at the CHP plant [50].

An alternative to the 'peak-shaving' boilers are booster HPs which can be used to increase the DH supply temperature when there is a deficit in the DH supply. These booster HPs are usually located at the periphery of the network. Utilization of booster HPs to increase the DH supply temperature when and where it is required is also viewed as a technology that would enable the option of applying ultra-low temperatures in DHSs [55-59]. From an economic viewpoint, depending on electricity price variations, these booster HPs could compete with gas boilers [57]. Furthermore, if used in combination with hot water storage tanks for hot tap water production, booster HPs can reduce DH morning peaks and provide energy cost-saving for end users [60]. The economic and energy efficiency benefits of using the distributed booster HPs to adjust heat in secondary networks during peak loads are even higher if the main DH production plants include $\mathrm{CHP}$ production and flue gas recovery systems [61]. The reason is that utilization of the HPs would simultaneously result in lower return-water temperatures, which would not only reduce the heat losses in the network, but also enable recycling of more waste heat from the turbine exhaust steam and from the flue gas during peak shaving. Thereby, the utilization of distributed HPs as a 'peak-shaving' strategy would result not only in energy and economic savings, but also in environmental benefits [61].

Another way to reduce the use of oil-fired peak boilers is by integrating distributed geothermal HPs in DH substations. However, due to the high investment costs, such a strategy would increase $\mathrm{DH}$ production costs; notwithstanding, it would also reduce $\mathrm{CO}_{2}$ emissions [54].

\subsection{Demand Side Management (DSM)}

A more detailed categorization of demand side measures that are part of $\mathrm{DH}$ load variation management is presented in Figure 5.

\subsubsection{Strategic Demand Increase}

The 'strategic demand increase' implies a demand increase that makes desirable changes to the DH load curve, i.e., increases the capacity utilization of the DHS. Examples of these desirable changes include increasing the base DH load demand (including demands that are more evenly distributed during a year, e.g., less dependent on outdoor temperature) and valley filling (increasing the DH demand during the periods with low DH demand, i.e., 'valley periods'). 


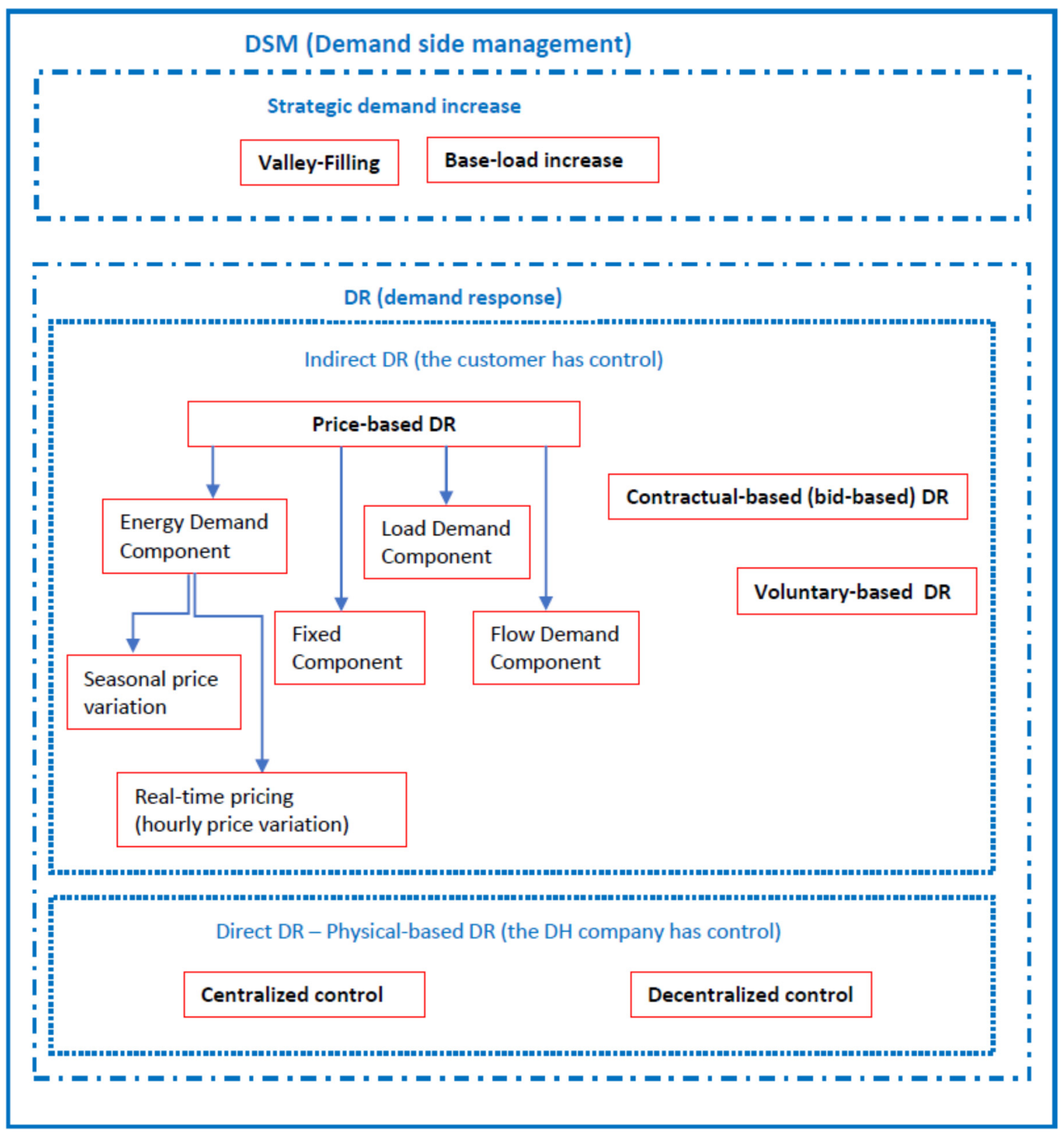

Figure 5. Proposed categorization of demand side measures that are part of DH load variation management.

One of the possible strategies to achieve a less outdoor temperature-dependent and more evenly distributed DH demand in DHSs is to increase the utilization of DH in industrial processes [11]. This type of heating demand is less dependent on outdoor temperature than the space heating demand, which is the major component of the aggregate heat load in most DHSs. However, this strategy requires consideration of heat loads for the industrial processes according to time dependency and the required temperature levels [11]. The highest potential for increasing the annual operating time of base-load $\mathrm{DH}$ plants can be found in drying processes (in the manufacture of wood, machinery and equipment, and food production), which are characterized by very constant demand curves, regardless of the work hours. The potential can also be found in heating processes (e.g., preheating water for dishwashing during food production and for washing clothes in the manufacture of textiles) and cooling processes (e.g., DH-driven absorption cooling in the manufacture of chemicals and chemical products; basic pharmaceutical products and pharmaceutical preparations; and rubber and plastic products) [12]. 
The most desirable demand increase when considering changes to the DH load curve is 'valley filling'. A well-known strategy to achieve this change is integration of DH-driven absorption cooling for comfort purposes within DHSs, since comfort-cooling demand is at its peak during the summer when the $\mathrm{DH}$ demand is lowest $[59,62,66]$. The cooling demand can be found in both domestic and industrial sectors. In fact, comfort cooling is the industrial support process with the highest potential to reduce a $\mathrm{DH}$ load variation when converting to DH-driven absorption cooling [12,67]. The economic and environmental benefits of this strategy are even higher when the comfort cooling converts from compression to absorption cooling that is integrated within a CHP-based DHS. Firstly, in this case the increased $\mathrm{DH}$ production during the summer would increase income from CHP electricity production. Secondly, and equally important, the electricity used for compression cooling (which is probably produced in fossil fuel-based condensing power plants) would be replaced with biomass- or waste-based CHP electricity production [13,63,64,66].

Equally relevant as a strategy for 'valley filling' is a theoretical possibility to increase DH production during the summer by converting heat to other types of energy, which can be stored for later consumption. This strategy (converting one type of energy to another for storage purposes) was recognized by Görnsson and Johnsson [135] as one of the functionality-based categories of load variation management strategies related to the electricity sector, where it is called 'absorbing'. In regard to the electricity sector, 'absorbing' is a strategy where the electricity is converted to another type of energy during the periods with low electricity demand and price (e.g., power-to-gas and power-to-heat) in order to be stored with reduced costs. A corresponding strategy related to DHS is, for example, the integration of pellet production with CHP production, where the drying process for pellet production is maximized during periods with low DH demand in the DHS [65,68]. The pellets produced during these periods can be stored for later consumption.

\subsubsection{Demand Response (DR)}

DR strategies rely on demand side flexibility and are focused on achieving desirable changes to the load profile to optimize the entire system. These strategies require control and communication systems between DH companies and customers.

Various studies distinguished between different categories of DR strategies related to electricity systems. The most usual classification of DR strategies related to the electricity system is based on motivators for the customers: (1) price-based motivator and (2) incentivebased motivator [140-143]. The incentive-based DR were described differently in the various studies. Some of the categories of incentive-based DR are direct load control, interruptible service, and emergency DR [1,140-142]. Ahmad et al. [142] also suggested DR classifications based on control information (centralized or distributed).

A more general classification of the DR measures would be indirect and direct DR $[1,144]$. Indirect DR is based on the communication between the customer and the operator, but the customer has complete control. Direct DR is more contractual and includes obligations. Direct DR requires special equipment with advanced technologies, which enables the company/operator to schedule supply to the customer. The decision is taken at the system level and the goal is to enhance the efficiency of the entire system [1]. After reviewing the articles on DR strategies related to DHSs, the above-mentioned classifications of DR strategies were put in DHS concepts, and a classification of DR measures related to the DHSs was proposed (Figure 5).

\section{Direct DR}

Using heat stored in the buildings connected to $\mathrm{DH}$ networks to reduce the $\mathrm{DH}$ demand peaks (i.e., using the buildings for so-called 'virtual' storage) is one of the strategies that has attracted increasing attention during the last years, especially in Italy $[25,69-74]$ and in Nordic countries, such as Finland [30,75-77], Denmark [78-85], and Sweden [54,86,87]. These countries are characterized by well-developed DH sectors and a large proportion of buildings with high thermal inertia. The strategy implies peak shaving by turning off 
heat delivery (usually for space heating purposes) for chosen customers during the peak demand hours. The duration of the shutdown periods can be a few hours, or even longer, without compromising indoor comfort. This strategy is usually mainly focused on morning hours peak shaving as the morning DH demand peak is one of the major concerns of DH companies. In addition to peak shaving, use of the buildings for virtual storage can benefit the electricity sector by enabling better interaction between electricity and DH sectors (i.e., increasing CHP electricity production) [30,31].

Even though preheating is not necessary [78-80], it is usually favorable and highly effective at increasing DH delivery before the shutdown periods [82]. In combination with preheating, the impact of shutdown on indoor temperature is lower, so the shutdown period can last longer $[78,79]$. However, preheating does not have the same effect on all buildings [79]. In addition to preheating, the duration of a shutdown period during which the indoor thermal comfort would still be acceptable depends on the outside temperature, the passive solar gains, and the building's characteristics $[79,88]$.

A building's potential to be used for virtual storage can be presented using several indicators: the thermal capacity of the building (the amount of the heat which can be stored in the building); the thermal autonomy potential; the DH saving potential (depends on the building's heat demand); and the economic savings potential. The building's thermal capacity and autonomy potential mostly depend on the building's thermal mass and the insulation level. Two values that are usually used to describe the building's thermal properties are time constants and degree hours. While the time constant describes how fast a building will be affected by heat delivery changes, the degree hours can be used as a measurement of TE storage capacity $[79,87,88]$. Due to lower insulation standards, older buildings usually have higher DH demands and therefore higher switchable DH loads, but also shorter thermal autonomy potential. For these buildings, the outside temperature has a dominant impact on the thermal autonomy potential [88]. The most recent builds with a well-insulated envelope can maintain a longer shutdown period without compromising indoor thermal comfort (e.g., $6 \mathrm{~h}$ and longer) [79].

This strategy where buildings are used for virtual storage may also cause undesirable effects on the DHS. The strategy can result in new peaks during the preheating periods and directly after the DH delivery shutdown $[79,89]$. The magnitude of the peaks that follow the shutdown depends on the maximum capacity of the building's heating system. The reason is that, due to the sudden drop in the indoor temperature after shutdown, the capacity of the heating system would probably be fully utilized [79]. Older buildings have higher peaks after shutdown because, even if a building has undergone energy refurbishment, the maximum capacity of its heating system will remain the same as that dimensioned for the original construction phase of the building [79]. Furthermore, although the primary energy use can be reduced [54], this is not always the case. In some cases, an even higher energy use may occur $[76,82,83]$, e.g., if the control is price-based, the increased energy use will probably occur when the $\mathrm{DH}$ price is low $[81,82]$.

The control strategy must be planned individually for each specific DHS, taking into account the overall efficiency of the system [27], and not only the present conditions, but also the possible changes in the customers' DH demand profiles [76]. The choice of controlling strategy for a building should also be based on the service provided by the building [88]. Related to this, several studies were performed to propose controlling strategies for residential apartment buildings $[54,77,78,80,82,88,90]$, residential single-family houses [79,88,91], and offices [30,75-77,89].

To overcome the challenges related to the utilization of buildings for virtual storage, it is important to enable deployment of a cost-effective monitoring and communication infrastructure [89]. This multi-agent based control system should consist of two parts: one which focusses on the system (aims: to collect temperature data from the buildings, to calculate the total DH load, and to distribute the control strategies to the buildings), and one which focusses on the entity (aims: to adjust the building temperature, to calculate the new room temperature, and to send it to the main controller) [39]. The most fundamental 
components of such a controlling system are smart meters, which measure DH flows and exchange information on DH consumption, and the status of the $\mathrm{DH}$ network between $\mathrm{DH}$ companies and customers [92].

The strategy can be applied (1) at building level by remotely controlling the heat flux provided to the customers from individual substations [93], or (2) at room level by remotely controlling individual digital thermostatic radiator valves $[30,75,78,80,89,94]$, or (3) by remotely controlling an entire area or building clusters (i.e., the buildings clustered into different groups based on similar characteristics) $[39,72,86,95]$. When applying the strategy at room level, the modulation should not be similar in all rooms. The set-point temperature for each room should be individually adjusted depending on the room's function and on the occupants' heat perception [31,75]. While the clustering approach allows a larger peak reduction [72], applying the strategy at room level enables the utilization of the building's ability to contribute with demand flexibility to its full potential [75].

The control actions can be applied based on weather forecasts [81], DH price forecasts [30], marginal heat production costs [82], or real price signals [81]. They can be based on a day-ahead hourly schedule [30,94] or selected even more frequently, such as once every 15 min (real-time control) [95]. However, if the control action is based on the status of the entire DH network (e.g., real price signal), a synchronized response of the DH customers can be expected, which may cause the total peaks to shift instead of reducing them $[81,84]$.

\section{Indirect DR}

Indirect DR is based on communication between the customer and the operator and the customer has complete control. Depending on the implementation method, distinction can be made between indirect DR related to the electricity systems: (1) contractual-based (bidbased), (2) voluntary-based, and (3) price-based DR [1]. Contractual-based DR implies that the customer has responsibility to reduce consumption during peak load hours according to a previously signed contract. If the customer responds in critical times, he/she receives an incentive (e.g., discount on the bill, bill credit, or incentive payments distinct from the bill), but if the customer neglects to fulfil their contractual obligations he/she will be penalized. In contrast, voluntary-based DR implies that customers who respond in critical times receive an incentive but, if they do not respond, the only penalty would be rejection from the DR program [1]. Price-based DR has been recognized as a highly effective measure for the electricity sector [145]. Categorization of price-based DR related to the electricity sector differs from study to study, but generally, distinction can be made between static pricing (e.g., 'time of use' tariffs and so called 'flat-tiered' prices) and dynamic pricing (e.g., critical peak pricing and real-time pricing) $[137,142,143]$. However, due to the monopolistic nature of $\mathrm{DH}$, it is difficult to apply the same price models to $\mathrm{DH}$.

Since DSM is based on an idea that the overall efficiency of the DHS is more important than the quality of service for individual customers, there is a need for customers to act responsibly [27]. As a result, the customers' role will likely become more significant in the future [76]. Moreover, a demand measure is more attractive if the demand side stakeholders (including the customers) have control over its application (i.e., indirect DR measures), despite the fact that this requires a more complex system for interaction between the supply and demand sides of the DHS [96].

Unfortunately, using residential buildings to manage the DHS's flexibility is usually not compatible with the households' DH consumption patterns [83]. For this reason, to be able to make the customers' DH consumption more flexible, the demand side measures must be based on understanding the customers' everyday practices [97], and it must include incentives for the customers that acknowledges their willingness to enact energyand cost-savings [76].

However, the customer's economic benefit does not necessarily imply economic benefit for the DH company [76]. In order to make a measure sufficiently economically sustainable and attractive to be implemented on a large scale, economic benefits generated 
by the measure should be shared, not only between the $\mathrm{DH}$ companies and the $\mathrm{DH}$ customers [30,76], but also between all involved stakeholders [96]. Moreover, successful implementation of the measure relies on clearly defined and communicated operating rules related to the responsibilities of the stakeholders, and on establishing collaborative governance in the DHS [96].

The willingness on the part of the customers to participate in a DR program can be created by economic or environmental incentives. Even though no examples of voluntarybased DR strategies related to DH have been found in the literature review, this category is proposed in this study as one of the indirect DR categories. The voluntary-based DR would, above all, rely on disseminating the information, and on education of the demand-side stakeholders (on potential environmental benefits, for example).

Applying indirect DR in DHS usually involves overcoming several technical, market, and organizational challenges [98]. One organizational challenge is that a regulated market does not allow DH companies to adjust their DH prices [99]. One of the market barriers is group metering and billing of $\mathrm{DH}$ use, which is sometime practiced. Since the attractiveness of indirect DR relies on providing incentives to the end-users, group metering and billing reduces the effectiveness of the measure by splitting the incentives between the customers connected to a group meter [98].

Since the price-based DR implies customers' modulation of DH use, these price signals should be generated by considering the customers' consumption profiles [100]. However, if the same price signal is sent to all customers in the DHS, the aggregated DR to a price signal may result in formation of new and even larger peaks during the hours when the DH price is low [101]. In order to avoid creating new peaks, the DH companies could send different signals to different areas of the DH network [98], or could apply additional constraints that guarantee a more evenly distributed DR, even though these constraints may reduce the potential to shift DH consumption out of peak hours [101].

DH pricing models may play a decisive role for the sustainable development of DHSs [99]. A DH price model is usually composed of few components. For example, in Nordic countries the components used in DH price models are energy demand, load demand, flow demand, and a fixed component.

The Energy Demand Component (EDC) is a variable component which is used to cover the operation and maintenance costs of DH companies, but also aims to encourages energy savings during periods with higher $\mathrm{DH}$ demand (i.e., higher $\mathrm{DH}$ prices), and in some cases to make the $\mathrm{DH}$ competitive with alternative heat production methods (e.g., heat production by HPs during the summer when the electricity price is lower). The EDC usually varies seasonally; however, if smart heat metering systems are included, the EDC can even be presented by real-time DH prices (based on the marginal DH production costs). While a seasonal price variation increases the DH customer's interest in reducing their seasonal variation of DH demand (i.e., $\mathrm{DH}$ use for space heating), the real-time price variation would encourage them to reduce their daily demand peaks, e.g., by adapting their behavior and reducing hot-tap water use [99,100].

The Load Demand Component (LDC) is usually based on the customer's measured peak load demand during the few coldest days of the year. This component aims to cover the companies' investment costs in the capacity reserved for that specific customer and, because of this, the charge is calculated by multiplying the customer's peak load demand $(\mathrm{kW})$ by a price for a unit of load demand $(€ / \mathrm{kW})$. A pricing model that includes an LDC is an effective way to reduce the $\mathrm{DH}$ peak load, because it encourages the customers to change their consumption pattern to reduce their energy costs [100]. An LDC based on a daily resolution motivates the customers to reduce their peak demand at the same resolution, e.g., by using the building's thermal mass as short term heat storage or by applying energy efficiency measures that would give a lower space-heating demand (e.g., better house insulation) [100].

The Fixed Component (FXC) is also based on the customer's estimated/measured peak load demand. However, in this case, the charge is not calculated by multiplying the 
customer's peak load demand $(\mathrm{kW})$ by a price for a unit of load demand $(€ / \mathrm{kW})$. It is instead based on a level in which the customer's peak load demand is staged [100]. The customers are grouped based on the level in which their peak load demands are staged (e.g., under $50 \mathrm{~kW}$, between $50 \mathrm{~kW}$ and $100 \mathrm{~kW}$, between $100 \mathrm{~kW}$ and $250 \mathrm{~kW}$ ), and all customers with the peak demand within the same level are paying the same charge. Since the levels can have wide intervals, it can be problematic for a customer to reduce the peak load demand sufficiently to change the price level. Therefore, this component is not equally effective in encouraging customers to reduce their $\mathrm{DH}$ consumption patterns.

The Flow Demand Component (FDC) is based on the volume of hot water needed to deliver the heat energy to the customer. It covers the pumping costs and heat losses in the network [100]. The DH flow is directly affected by efficiency of all heat exchangers in the DH substation and in the customer's internal distribution network [9]. Therefore, this price component aims to encourage the customers to improve the efficiency of the heat exchangers over which they have control (e.g., to invest in more efficient radiators and, if they have control, to invest in more efficient heat exchangers in their DH substation) [100].

\subsection{Thermal Energy Storage}

The volume of literature published on TES systems is considerable. Classification of TESs can be based on several criteria [102-104,106,115]. Alva et al. [104] classified TES depending on (1) storage duration (seasonal and short-term TES), (2) temperature (cold, low, medium and high temperature; within a range from $-40{ }^{\circ} \mathrm{C}$ to $600{ }^{\circ} \mathrm{C}$ ), (3) type of storage materials (sensible, phase change, and thermochemical heat storage materials), (4) need for pumping to circulate the hot water during operation (active and passive TES), and (5) how the heat is stored and delivered (centralized, building end, and mobile TES). Guo et al. [106], on the other hand, presented a different classification of TES systems in terms of (1) main technical characteristics (capacity, storage time, storage density, charging/discharging limits, efficiency), (2) temperature, (3) position in the heating networks, and (4) storage materials (direct-sensible hot water tank, and indirect-latent using Phase Charge Material or Borehole thermal storage in soil). Zhang et al. [103] provided a comprehensive review of TES systems based on design, technology, type of storage materials, and heat carrier. The criteria relevant for classification in this study reflect the timeframe within which the DH load is affected (hours, days, months). Accordingly, TESs are classified as long-term and short-term TESs (Figure 6).

\subsubsection{Long-Term TES}

The purpose of seasonal and weekly TESs is to store heat for long periods of time. Seasonal TESs are characterized by large capacity (large-scale TES), cheap building materials, low operating temperatures (the temperature range of $20^{\circ} \mathrm{C}-80^{\circ} \mathrm{C}$ ), and long storage duration (long-term TES) [104]. Besides (1) increasing the capacity utilization of the existing DH plants and (2) avoiding DH production in natural gas or oil-fired peak-load plants with high operation costs during the winter [105], the large-scale TESs are crucial for (3) exploiting solar collectors in solar DHSs at their best [106-111], (4) increasing annual utilization of industrial excess heat delivered to the DHS [112-114], (5) avoiding heat wastage from waste incineration plants, which still have to treat waste during the summer when the DH demand is low [115], and (6) improving the performance of integrated heating and cooling systems [116,117]. Xu et al. [108] reviewed and compared all three available technologies for large-scale TES (sensible, latent and chemical TES) in terms of development and energy storage densities. The results showed that while the sensible TES is a mature technology that has been demonstrated in many large-scale DH plants, latent and chemical TES technologies are still developmental. However, both technologies are characterized by much higher energy storage densities compared to sensible technologies and are therefore interesting for further development. 


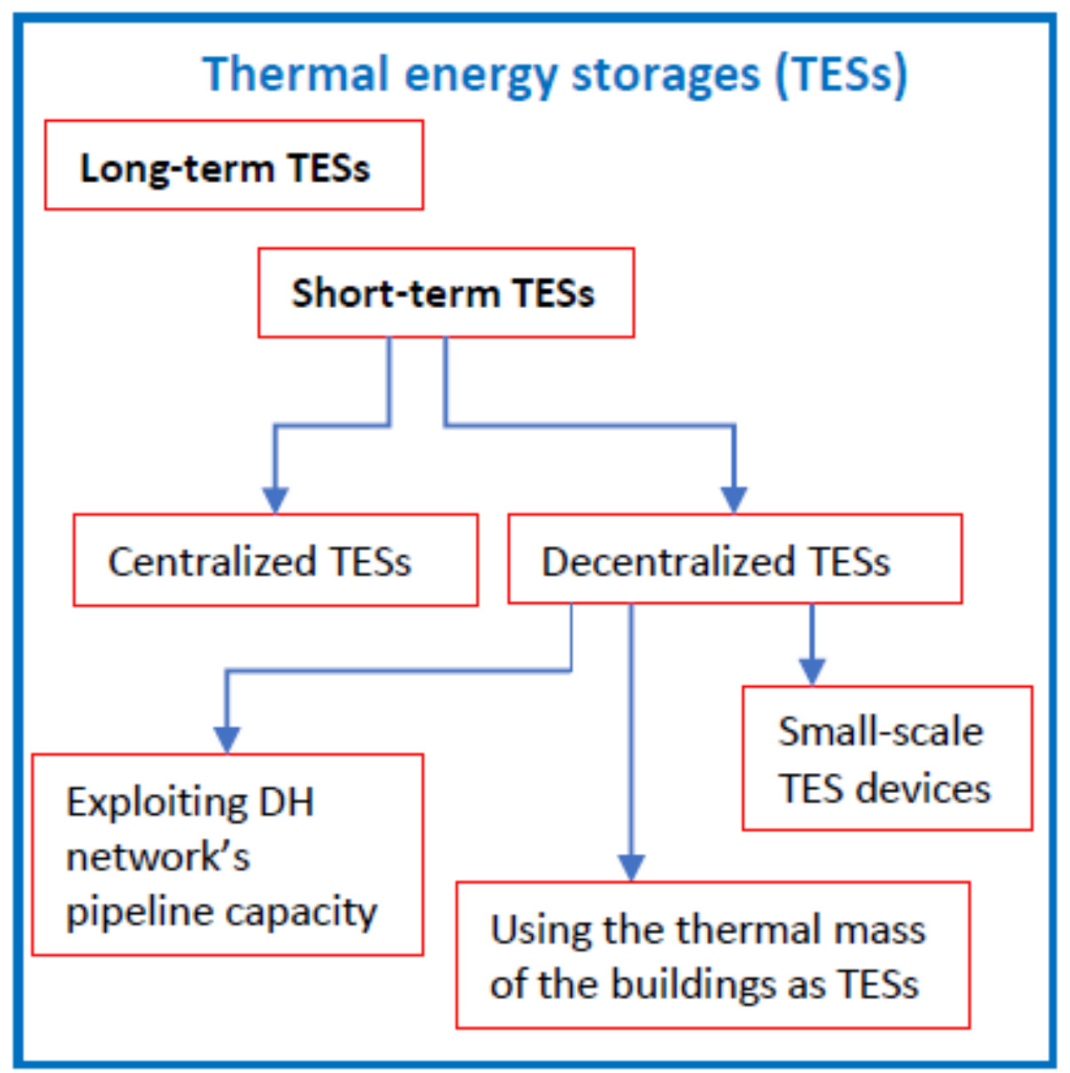

Figure 6. The proposed classification of long-term and short-term TESs.

\subsubsection{Short-Term TES}

Short-term TES can provide peak-shaving and load-shifting in DHSs over a time period from an hour to up to a few days, and hence enable a flexible load shape in the system. The short-term TESs can be used to reduce the mass flow rate through the bottlenecks in the DHS [26], as well as to improve economic performance of CHP plants and HPs by enabling their flexible utilization depending on the electricity price variation. These TESs can be centralized or decentralized. The location is usually related to the function performed by the TES.

\section{Centralized Short-Term TES}

Centralized TESs usually provide load-shaping of the whole (aggregated) heat load of the DHS, and hence decrease the total DH production costs in the system. The most common TES configuration is centralized short-term TESs located close to the CHP plant or incorporated in CHP installation. These TESs aim to provide load flexibility and thereby to increase the operating time of the CHP plant [118-121]. As a result of the improved performance of the CHP plant, there is potential to reduce global greenhouse gas emission [119], and to improve the economics of the CHP plant [122], in particular if the daily variation in the electricity price is considerable $[119,120]$. Centralized short-term TESs can also be used to improve energy and economic performance of integrated heating and cooling systems which are supplied by HPs and use DHSs as backup. This strategy requires an advanced control system, and the possible savings achieved is highly dependent on the electricity and DH price variations [117].

\section{Decentralized (Distributed) Short-Term TES}

Decentralized TES can be a collection of individual storage units located close to the individual dwellings (e.g., small buffer tanks) or in the individual dwellings (e.g., floor thermal storage systems [126]. A decentralized TES system can have a significant capacity available for heat storage. There is a wide variety of TES technologies that can be combined 
with buildings. This implies a challenge when choosing the most suitable TES technology depending on the building type [127], as well as when choosing the load shifting control strategy depending on the TES technology [128].

In addition to the TES units, the capacity to shift $\mathrm{DH}$ production over time can be found in the thermal inertia of the DH network itself. By raising the supply temperature of the $\mathrm{DH}$ water when the $\mathrm{DH}$ demand is low, a limited amount of heat can be temporarily stored in the DH network (i.e., the network can be pre-loaded/pre-charged) until the time when heat demand peaks [9]. This strategy can also be used to decrease DH load variation to mitigate the problem of limited variability of base load plants in the system [129]; to decrease the mass flow rate through the network bottlenecks during peak demand periods [26]; and to enable CHP production that would coordinate the operation of an electric power system with a high share of intermittent renewable electricity production (wind power production) $[130,134]$. However, because this frequent cycling of DH water between higher and lower temperatures increases material fatigue (especially for steel pipes), and because it can only be achieved using an advanced control strategy, it is not applied systematically by DH network operators, even though pre-loading the DH network is a well-known strategy for achieving flexibility in DHSs $[9,129,131]$. Another problem are the uncertainties related to modeling transient behavior of a DH network as it is not feasible to include all substations and network sections when building a model of the DH network for operational optimization [132]. The potential for peak load reduction using this strategy varies in different case studies.

Another way to pre-charge the DH network is to increase the flow rate through the pipes while maintaining a constant DH supply temperature [133]. However, to enable the desired change in the mass flow rate, it may be necessary to install new bypass pipes in the DH network. The potential for using a DH network as TES by applying flow rate variations depends on several factors, such as the duration of the flow adjustment, average velocity of the heat carrier fluid, the DH demand patter, and the network topology. In addition to the network pipes, the thermal mass of the buildings can be used as decentralized short-term heat storage units as well. This strategy was presented in Direct DR.

\section{Comparison between Different TES Solutions}

Theoretical potentials of a centralized TES (e.g., a water tank) and a decentralized TES system (e.g., multiple smaller storage tanks located in the individual dwellings) to create flexibility in CHP production in a DHS differ significantly. If the centralized TES and the decentralized TES system have the same storing capacities, the centrally located heat storage enables much higher flexibility in the DHS compared to the decentralized TES system. The reason is that every decentralized buffer meets only the DH demand of the respective individual dwelling, so every time the capacity of one of the buffers is too low the CHP must engage, which affects the available flexibility [123]. Moreover, compared to TES in the thermal mass of buildings, centralized TES with a similar maximum storage capacity can store more than twice as much heat annually. The reason is that the full storage capacity of the thermal mass of buildings is not always available for charging/discharging since the capacity depends on the heat transfer between the building core and its indoor air. The central TES can also provide load-shifting over a longer time period [124]. However, the potential to increase network flexibility and the profit from the CHP is highly dependent on the TES capacity; this can give the opposite result if the centralized TES has a lower capacity than the decentralized TES system [31].

Compared to utilization of DH networks as TES, centralized TES units can store up to ten times more heat annually, especially in the case of small networks which have insufficient heat storage capacity. Furthermore, network storage can usually be used only for a few hours for load-shifting. Other problems related to storing heat in DH networks include uncertain storage capacity, increased stresses on the physical components in the network, and increased heat losses due to the increased return temperature. However, using a DH network as TES is still an attractive TES solution because there are no additional 
costs [125], particularly in combination with the TE storage in the thermal mass of the building [134]. When applied separately, these two TES solutions have different potentials, benefits, and disadvantages. TE storage in the thermal mass of the buildings would provide much higher flexibility of DH production in the system, compared to using a DH network as TES [134]; however, this strategy requires investments in more complicated control and communication systems between DH companies and customers.

\section{Discussion}

Complementing DH production is $\mathrm{DH}$ production in $\mathrm{DH}$ sources that are connected to a primary or secondary DH network and are usually invested in and controlled by a DH company. Some of the complementing DH sources can even be invested in and controlled by the $\mathrm{DH}$ customers. However, in this case there is no guarantee that these $\mathrm{DH}$ sources would be used in a manner that the DH load variation is reduced, because the customers' decisions on how to run the DH sources may be based on incentives from another system. An example is the use of private geothermal HPs as a complement to a DH. The customers would probably rather run the HPs during the summer, when the electricity price is low, than during the winter. This will have consequences as an even lower capacity utilization in the local DHS. In order to avoid this problem, the DH producers must consider not only the variation in marginal $\mathrm{DH}$ production costs during the year, but also the electricity price variation, when deciding the seasonally varied energy demand component of the $\mathrm{DH}$ price model.

TE can be stored in TES units included as complementing parts of the DHS, or even in the DH network's pipes and thermal mass of the buildings connected to the DHSs. Usually the DH company is responsible for controlling TE storage. Use of the DH network to store the heat is a strategy which is usually integrated in the operating schedule. Increasing the supply temperature in the network before a peak demand occurs, avoids an increased mass flow through the network's bottlenecks during the peaks. However, this strategy, as well as storing the heat in the thermal mass of the building before the peaks, requires good insight in daily heat load variation as well as short-term heat load forecasting.

The DSM measures in the DHSs can be categorized as (1) a group of measures applied on the existing demand side (so called 'demand response' measures), and (2) 'strategic demand increases' which make desirable changes to the DH load curve. The strategic demand increases are commonly initiated by DH producers, while the DR measures can be further categorized as (a) direct DR measures which are controlled by the DH company, and (b) indirect DR measures that are based on communication between the DH company and the customer, but are completely controlled by the DH customer.

Both types of DR measures require an advanced monitoring and communication system, which would, for example, monitor the temperature data from the buildings, calculate the aggregate DH load, and distribute the information and control signals. The system should focus not only on the conditions of the whole system, but also on the conditions of the individual customers (e.g., DH load demand variations, potential for heat storage in a building, special temperature requirements). However, above all, these types of measures rely on cooperation between the DH company and consumers.

Moreover, the possible benefits of the DH load management measures expand the DHS boundaries because these measures may also benefit the electricity system (1) by increasing the electricity production in biomass-fired CHP plants, and (2) by enabling an increased share of intermittent power sources (by running the heat storage units, CHP electricity production and electricity-based $\mathrm{DH}$ production depending on the electricity production in the intermittent sources). However, this cooperation would require not only a more complicated monitoring and communication infrastructure (between the $\mathrm{DH}$ companies, electricity companies and DH customers), but also energy policies that support this cooperation. This implies that in addition to the DH companies and consumers, other stakeholders that should be interested in possible DH load management measures are 
electricity producers, local governments, policymakers, etc. Therefore, this subject requires a more interdisciplinary approach.

\section{Limitations of the Study}

Although a large number of search strings were used during the systematic literature review, one limitation is the use of only two databases ('Web of Science' and 'Scopus'). This limitation was reduced by including many cross-references.

The quality of the reviewed publications differed from study to study. A further weakness is that most of the included publications are case studies. Consequently, the results presented in these publications are based on local conditions related to the analyzed DHSs (climate conditions, characteristics of the building sector, availability of the local resources, characteristics of the electricity sector, etc.).

Moreover, in order to detect as many measures as possible, the geographic area in which the publications originated was not limited. Although this enabled inclusion of more publications in the study, it also presented challenges during the data extraction and synthesis process because of the different terminologies and trends in certain geographical areas. For instance, while in some countries utilization of natural gas-fired HOB during peak demand is considered a problem that should be solved (e.g., in the EU), in the countries where the largest proportion of $\mathrm{DH}$ is produced by coal, $\mathrm{DH}$ production in the natural gas-fired HOB during peak demand is seen as a solution to the problem (e.g., China). Therefore, different terms are also used when referring to the natural gas HOBs ('peak-load $\mathrm{HOB}^{\prime}$ in EU and 'peak-shaving $\mathrm{HOB}^{\prime}$ in China).

Furthermore, the multi-disciplinary nature of this topic requires an interdisciplinary approach in order to provide a comprehensive picture of the possibilities, challenges, and potential trade-offs associated with a DH load management measure. However, only a few publications detected during the literature review covered social and political aspects.

\section{Conclusions}

DH load management measures can be categorized into three main categories: complementing DH production; TE storage; and DSM measures.

Measures that can be applied to manage the seasonal variation are investment in long-term TESs and complementing DH production (HOB or HP), as well as demand side measures, such as strategic demand increase (base-load increase and valley-filling), and indirect DR measures which encourage the customers to reduce their DH demand during the winter. Investing in better housing insulation and lowering the indoor temperature are two ways to reduce DH use for space heating during the winter. This can be encouraged not only by an energy demand component, but also by a load demand component in the $\mathrm{DH}$ price model. A load demand component based on a daily resolution and a charge calculated per unit of load demand $(\mathrm{kW})$ may also motivate the customers to reduce their daily DH load variation. The fixed (load) component, where the charge is not based on a unit $(\mathrm{kW})$, but instead on a level in which the customer's peak load demand is staged cannot motivate the reduction of the daily DH load variation. The stage intervals for the load demand on which charging is based are wide therefore, to reduce the charge for the fixed (load) component, the customers would probably need to invest in larger insulation projects that would result in a reduction of the seasonal, rather than the daily, DH demand variation. DH production during the winter can also be reduced by investing in more efficient heating systems (i.e., larger radiators); this is usually encouraged by the flow demand component of the $\mathrm{DH}$ price model.

The investments by the $\mathrm{DH}$ producer (e.g., in complementing $\mathrm{DH}$ production) or by the DH customer, as well as strategic demand increase (e.g., absorption cooling or DH utilization in industrial processes), have permanent effects on the DHS. These measures usually manage the seasonal load variation but can also manage the daily $\mathrm{DH}$ load variations (e.g., investments in more efficient elements in the hot-tap water supply system). This is in contrast to the changes in the DH customers' behavior, which mostly affects the 
daily DH load variations. In addition to the energy demand component of the $\mathrm{DH}$ price model, measures that motivate changes in the customers' behavior are voluntary-based and contractual-based (bid-based) indirect DR.

Other measures that can be used to manage the daily DH load variations are shortterm heat storage in centralized and decentralized TES units; refraining from part of CHP electricity production in order to produce more $\mathrm{DH}$ during peak demand; heat storage in the DH network and in the thermal mass of the buildings connected to the network; DH production in distributed peak-shaving HOB; and geothermal and booster HPs. While the voluntary-based indirect DR is a measure that may only reduce the daily DH load variation temporarily (i.e., there is no guarantee that the customers will respond every time a peak load occurs), all other mentioned measures can be integrated in an optimized DH production schedule. However, in order to develop such a DH production schedule, reliable short-term DH load demand forecasting is necessary.

Funding: This research received no external funding.

Institutional Review Board Statement: Not applicable.

Informed Consent Statement: Not applicable.

Data Availability Statement: Data is contained within the article.

Conflicts of Interest: The author declares no conflict of interest.

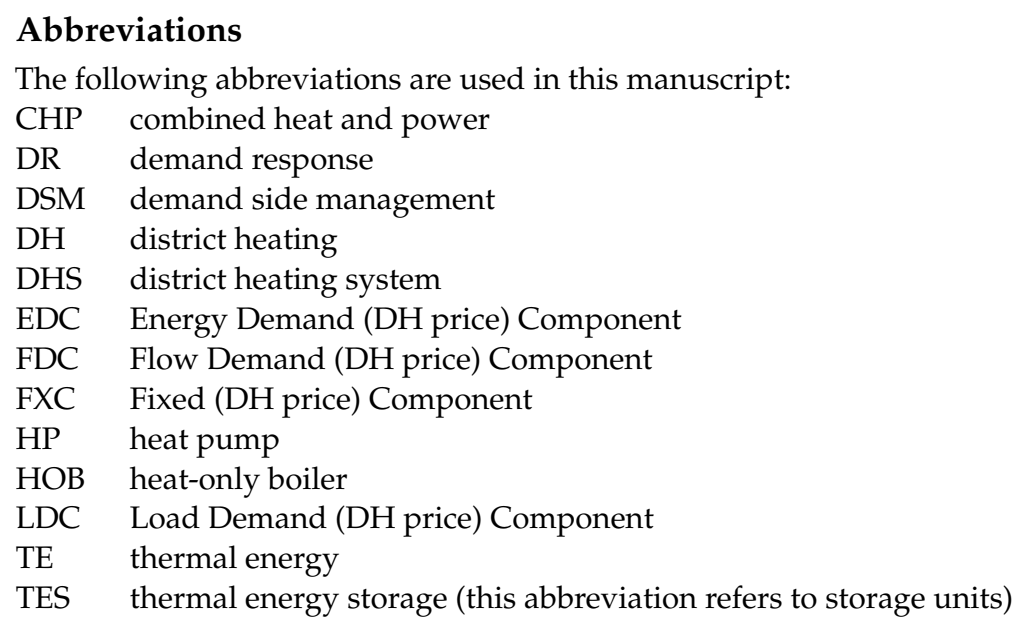

\section{References}

1. Meyabadi, A.F.; Deihimi, M. A review of demand-side management: Reconsidering theoretical framework. Renew. Sustain. Energy Rev. 2017, 80, 367-379. [CrossRef]

2. Söder, L.; Larsson, S.; Dahlbäck, N.; Linnarsson, J. Reglering av ett Framtida Svenskt Kraftsystem Report; NEPP—North European Power Perspective, 2014. Available online: https://www.nepp.se/etapp1/pdf/Reglering_av_vindkraft_20141118_ren.pdf (accessed on 18 December 2020).

3. Söder, L. På Väg Mot En Elförsörjningbaserad På Enbart Förnybar El I Sverige: En Studie Om Behov Av Reglerkraft Och Överföringskapacitet. Version 4.0; KTH Royal Institute of Technology: Stockholm, Swede, 2014.

4. Werner, S. International review of district heating and cooling. Energy 2017, 137, 617-631. [CrossRef]

5. Lund, H.; Möller, B.; Mathiesen, B.V.; Dyrelund, A. The role of district heating in future renewable energy systems. Energy 2010, 35, 1381-1390. [CrossRef]

6. Connolly, D.; Lund, H.H.; Mathiesen, B.V.; Werner, S.; Moller, B.; Persson, U.; Boermans, T.; Trier, D.; Ostergaard, P.A.; Nielsen, S. Heat Roadmap Europe: Combining district heating with heat savings to decarbonise the EU energy system. Energy Policy 2014, 65, 475-489. [CrossRef]

7. Ilić, D.D. With District Heating toward a Sustainable Future: System Studies of District Heating and Cooling That Interact with Power, Transport and Industrial Sectors. Ph.D. Thesis, Linköping University, Linköping, Sweden, 2014.

8. Connolly, D.; Mathiesen, B.V. A technical and economic analysis of one potential pathway to a $100 \%$ renewable energy system. Int. J. Sustain. Energy Plan. Manag. 2014, 1, 7-28. [CrossRef]

9. Frederiksen, S.; Werner, S. District Heating and Cooling, 1st ed.; Studentlitteratur AB: Lund, Sweden, 2013.

10. Werner, S. Energiförsörjning-En Introduktion Till Vårt Energisystem; Studentliteratur AB: Lund, Sweden, 2016. 
11. Difs, K.; Danestig, M.; Trygg, L. Increased use of district heating in industrial processes-Impacts on heat load duration. Appl. Energy 2009, 86, 2327-2334. [CrossRef]

12. Ilic, D.D.; Trygg, L. Economic and environmental benefits of converting industrial processes to district heating. Energy Convers. Manag. 2014, 87, 305-317. [CrossRef]

13. Trygg, L.; Amiri, S. European perspective on absorption cooling in a combined heat and power system-A case study of energy utility and industries in Sweden. Appl. Energy 2007, 84, 1319-1337. [CrossRef]

14. Ilic, D.D.; Dotzauer, E.; Trygg, L. District heating and ethanol production through polygeneration in Stockholm. Appl. Energy 2012, 91, 214-221. [CrossRef]

15. Ilic, D.D.; Dotzauer, E.; Trygg, L.; Broman, G. Introduction of large-scale biofuel production in a district heating system-An opportunity for reduction of global greenhouse gas emissions. J. Clean. Prod. 2014, 64, 552-561. [CrossRef]

16. Danestig, M.; Gebremehdin, A.; Karlsson, B. Stockholms CHP potential-An opportunity for $\mathrm{CO}_{2}$ reductions? Energy Policy 2007, 35, 4650-4660. [CrossRef]

17. Knutsson, D.; Werner, S.; Ahlgren, E.O. Combined heat and power in the Swedish district heating sector-Impact of green certificates and $\mathrm{CO}_{2}$ trading on new investments. Energy Policy 2006, 34, 3942-3952. [CrossRef]

18. Gebremedhin, A. Introducing District Heating in a Norwegian town-Potential for reduced Local and Global Emissions. Appl. Energy 2012, 95, 300-304. [CrossRef]

19. Lund, R.; Ilic, D.D.; Trygg, L. Socioeconomic potential for introducing large-scale heat pumps in district heating in Denmark. J. Clean. Prod. 2016, 139, 219-229. [CrossRef]

20. Lund, H.; Münster, E. Integrated energy systems and local energy markets. Energy Policy 2006, 34, 1152-1160. [CrossRef]

21. Lund, H.; Werner, S.; Wiltshire, R.; Svendsen, S.; Thorsen, J.E.; Hvelplund, F.; Vad Mathiesen, B. 4th Generation District Heating (4GDH): Integrating smart thermal grids into future sustainable energy systems. Energy 2014, 68, 1-11. [CrossRef]

22. Østergaard, D.S.; Svendsen, S. Replacing critical radiators to increase the potential to use low-temperature district heating-A case study of 4 Danish single-family houses from the 1930s. Energy 2016, 110, 75-84. [CrossRef]

23. Werner, S. District heating and cooling in Sweden. Energy 2017, 126, 419-429. [CrossRef]

24. Schmitz, K. Energy Industry and Politics (in German: Energiewirtschaft Und Politik). The Energy Efficiency Association for Heating, Cooling and CHP, AGFW-Main Report, 2017. Available online: https:/ / www.agfw.de/zahlen-und-statistiken/agfwhauptbericht/ (accessed on 18 December 2020).

25. Guelpa, E.; Marincioni, L.; Deputato, S.; Capone, M.; Amelio, S.; Pochettino, E.; Verda, V. Demand side management in district heating networks: A real application. Energy 2019, 182, 433-442. [CrossRef]

26. Brange, L.; Englund, J.; Sernhed, K.; Thern, M.; Lauenburg, P. Bottlenecks in district heating systems and how to address them. Energy Procedia 2017, 116, 249-259. [CrossRef]

27. Wernstedt, F.; Davidsson, P.; Johansson, C. Demand side management in district heating systems. In Proceedings of the 6th International joint Conference on Autonomous agents and multiagent systems; ACM: Honolulu, HI, USA, 2007.

28. Guelpa, E.; Mutani, G.; Todeschi, V.; Verda, V. A feasibility study on the potential expansion of the district heating network of Turin. Energy Procedia 2017, 122, 847-852. [CrossRef]

29. Verda, V.; Colella, F. Primary energy savings through thermal storage in district heating networks. Energy 2011, 36, 4278-4286. [CrossRef]

30. Salo, S.; Jokisalo, J.; Syri, S.; Kosonen, R. The Effect of Demand Response on Perceived Thermal Comfort in a District Heated Office Building. In Proceedings of the 2018 15th International Conference on the European Energy Market (EEM), Lodz, Poland, 27-29 June 2018; pp. 1-5.

31. Vanhoudt, D.; Claessens, B.; Salenbien, R.; Desmedt, J. An active control strategy for district heating networks and the effect of different thermal energy storage configurations. Energy Build. 2018, 158, 1317-1327. [CrossRef]

32. Gadd, H.; Werner, S. Heat load patterns in district heating substations. Appl. Energy 2013, 108, 176-183. [CrossRef]

33. Gadd, H.; Werner, S. Daily heat load variations in Swedish district heating systems. Appl. Energy 2013, 106, 47-55. [CrossRef]

34. Dotzauer, E. Simple model for prediction of loads in district-heating systems. Appl. Energy 2002, 73, 277-284. [CrossRef]

35. Noussan, M.; Jarre, M.; Poggio, A. Real operation data analysis on district heating load patterns. Energy 2017, 129, 70-78. [CrossRef]

36. Idowu, S.; Saguna, S.; Åhlund, C.; Schelén, O. Applied machine learning: Forecasting heat load in district heating system. Energy Build. 2016, 133, 478-488. [CrossRef]

37. Hietaharju, P.; Ruusunen, M.; Leiviskä, K. A Dynamic Model for Indoor Temperature Prediction in Buildings. Energies 2018, 11, 1477. [CrossRef]

38. Li, H.; Wang, S.J. Load Management in District Heating Operation. Energy Procedia 2015, 75, 1202-1207. [CrossRef]

39. Dahl, M.; Brun, A.; Andresen, G.B. Using ensemble weather predictions in district heating operation and load forecasting. Appl. Energy 2017, 193, 455-465. [CrossRef]

40. Ivanko, D.; Walnum, H.T.; Nord, N. Development and analysis of hourly DHW heat use profiles in nursing homes in Norway. Energy Build. 2020, 222, 110070. [CrossRef]

41. Ivanko, D.; Sørensen, Å.L.; Nord, N. Selecting the model and influencing variables for DHW heat use prediction in hotels in Norway. Energy Build. 2020, 228, 110441. [CrossRef] 
42. Hasan, A.; Kurnitski, J.; Jokiranta, K. A combined low temperature water heating system consisting of radiators and floor heating. Energy Build. 2009, 41, 470-479. [CrossRef]

43. Peterson, S. Analys av Konventionella Radiatorsystem. Analysis of Conventional Radiator Systems. Licentiate Thesis, Chalmers University of Technology, Gothenburg, Sweden, 1998.

44. Gadd, H.; Werner, S. Achieving low return temperatures from district heating substations. Appl. Energy 2014, 136, 59-67. [CrossRef]

45. Wernstedt, F. Multi-Agent Systems for Distributed Control of District Heating Systems. Ph.D. Thesis, Blekinge Institute of Technology, Karlskrona, Sweden, 2005.

46. Jesson, J.K.; Matheson, L.; Lacey, F.M. Doing Your Literature Review: Traditional and Systematic Techniques, 1st ed.; SAGE Publications: Thousand Oaks, CA, USA, 2011.

47. Arksey, H.; O’Malley, L. Scoping studies: Towards a methodological framework. Int. J. Soc. Res. Methodol. 2005, 8, 19-32. [CrossRef]

48. Merrill, M.D.; Tennyson, R.D. Teaching Concepts: An Instructional Design Guide, 2nd ed.; Educational Technology Publications: Englewood Cliffs, NJ, USA, 1981.

49. Fang, H.; Xia, J.; Jiang, Y. Key issues and solutions in a district heating system using low-grade industrial waste heat. Energy 2015, 86, 589-602. [CrossRef]

50. Wang, H.; Lahdelma, R.; Wang, X.; Jiao, W.; Zhu, C.; Zou, P. Analysis of the location for peak heating in CHP based combined district heating systems. Appl. Therm. Eng. 2015, 87, 402-411. [CrossRef]

51. Liu, L. Major issues and solutions in the management system of space heating system in North China. Renew. Sustain. Energy Rev. 2015, 49, 221-231. [CrossRef]

52. Wang, H.; Jiao, W.-L.; Lahdelma, R.; Zou, P.-H. Techno-economic analysis of a coal-fired CHP based combined heating system with gas-fired boilers for peak load compensation. Energy Policy 2011, 39, 7950-7962. [CrossRef]

53. Wang, H.; Duanmu, L.; Wu, X.; Li, X.; Lahdelma, R. Operational strategies and pumping energy saving potential of the combined district heating system with peak-shaving gas-fired boilers in heating substations. Sci. Technol. Built Environ. 2020, 26, 1216-1230. [CrossRef]

54. Arnaudo, M.; Topel, M.; Puerto, P.; Widl, E.; Laumert, B. Heat demand peak shaving in urban integrated energy systems by demand side management-A techno-economic and environmental approach. Energy 2019, 186, 115887. [CrossRef]

55. Ommen, T.; Thorsen, J.E.; Markussen, W.B.; Elmegaard, B. Performance of ultra low temperature district heating systems with utility plant and booster heat pumps. Energy 2017, 137, 544-555. [CrossRef]

56. Ommen, T.; Markussen, W.B.; Elmegaard, B. Lowering district heating temperatures-Impact to system performance in current and future Danish energy scenarios. Energy 2016, 94, 273-291. [CrossRef]

57. Vivian, J.; Emmi, G.; Zarrella, A.; Jobard, X.; Pietruschka, D.; De Carli, M. Evaluating the cost of heat for end users in ultra low temperature district heating networks with booster heat pumps. Energy 2018, 153, 788-800. [CrossRef]

58. Østergaard, P.A.; Andersen, A.N. Economic feasibility of booster heat pumps in heat pump-based district heating systems. Energy 2018, 155, 921-929. [CrossRef]

59. Østergaard, P.A.; Andersen, A.N. Booster heat pumps and central heat pumps in district heating. Appl. Energy 2016, 184, 1374-1388. [CrossRef]

60. Knudsen, M.D.; Petersen, S. Model predictive control for demand response of domestic hot water preparation in ultra-low temperature district heating systems. Energy Build. 2017, 146, 55-64. [CrossRef]

61. Zhao, X.; Fu, L.; Wang, X.; Sun, T.; Wang, J.; Zhang, S. Flue gas recovery system for natural gas combined heat and power plant with distributed peak-shaving heat pumps. Appl. Therm. Eng. 2017, 111, 599-607. [CrossRef]

62. Carotenuto, A.; Figaj, R.D.; Vanoli, L. A novel solar-geothermal district heating, cooling and domestic hot water system: Dynamic simulation and energy-economic analysis. Energy 2017, 141, 2652-2669. [CrossRef]

63. Fahlén, E.; Trygg, L.; Ahlgren, E. Potential $\mathrm{CO}_{2}$ reduction by increased integration of absorption cooling in a Swedish district energy system. In Proceedings of the 24th International Conference on Efficiency, Cost, Optimization, Simulation and Environmental Impact of Energy, Novi Sad, Serbia, 4-7 July 2011.

64. Fahlén, E.; Trygg, L.; Ahlgren, E.O. Assessment of absorption cooling as a district heating system strategy-A case study. Energy Convers. Manag. 2012, 60, 115-124. [CrossRef]

65. Abrahamsson, C. Intergration of Pellet Prodution with Rya Combined Heat and Power Generation Plant in Göteborg. (Integrering av Pelletsfabrik Med Rya Kraftvärmeverk I Göteborg, in Swedish). Master's Thesis, Uppsala University, Uppsala, Sweden, 2008. Available online: https://stud.epsilon.slu.se/12285/1/abrahamsson_c_171031.pdf (accessed on 18 December 2020).

66. Trygg, L.; Difs, K.; Moshfegh, B. Absorption cooling in CHP systems-Old technique with new opportunities. In Proceedings of the Xth World Renewable Energy Congress, Glasgow, Scotland, 19-25 July 2008.

67. Difs, K.; Trygg, L. Pricing district heating by marginal cost. Energy Policy 2009, 37, 606-616. [CrossRef]

68. Axelsson, E.; Overland, C.; Nilsson, K.; Sandoff, A. Bio Energy Combine in District Heating Systems (Bioenergikombinat i Fjärrvärmesystem, in Swedish). Swedish District Heat Association, Report 2009:11. Available online: http://www.svenskfjarrvarme. se (accessed on 18 December 2020).

69. Guelpa, E.; Barbero, G.; Sciacovelli, A.; Verda, V. Peak-shaving in district heating systems through optimal management of the thermal request of buildings. Energy 2017, 137, 706-714. [CrossRef] 
70. Guelpa, E.; Marincioni, L.; Verda, V. Towards 4th generation district heating: Prediction of building thermal load for optimal management. Energy 2019, 171, 510-522. [CrossRef]

71. Verda, V.; Capone, M.; Guelpa, E. Optimal operation of district heating networks through demand response. Int. J. Thermodyn. 2019, 22, 35-43. [CrossRef]

72. Guelpa, E.; Deputato, S.; Verda, V. Thermal request optimization in district heating networks using a clustering approach. Appl. Energy 2018, 228, 608-617. [CrossRef]

73. Verda, V.; Guelpa, E.; Sciacovelli, A.; Patti, E.; Acquaviva, A. Thermal Peak Load Shaving Through Users Request Variations in District Heating Systems. Int. J. Thermodynam. 2016, 19, 168-176. [CrossRef]

74. Guelpa, E.; Verda, V. Optimization of the Thermal Load Profile in District Heating Networks through "Virtual Storage" at Building Level. Energy Procedia 2016, 101, 798-805. [CrossRef]

75. Salo, S.; Jokisalo, J.; Syri, S.; Kosonen, R. Individual temperature control on demand response in a district heated office building in Finland. Energy 2019, 180, 946-954. [CrossRef]

76. Kontu, K.; Vimpari, J.; Penttinen, P.; Junnila, S. City Scale Demand Side Management in Three Different-Sized District Heating Systems. Energies 2018, 11, 3370. [CrossRef]

77. Hietaharju, P.; Ruusunen, M.; Leiviskä, K.; Paavola, M. Predictive Optimization of the Heat Demand in Buildings at the City Level. Appl. Sci. 2019, 9, 1994. [CrossRef]

78. Christensen, M.H.; Li, R.; Pinson, P. Demand side management of heat in smart homes: Living-lab experiments. Energy 2020, 195, 116993. [CrossRef]

79. Dominković, D.F.; Gianniou, P.; Venturini, G.; Heller, A.; Rode, C. Utilizing thermal building mass for storage in district heating systems: Combined building level simulations and system level optimization. Energy 2018, 153, 949-966. [CrossRef]

80. Beltram, L.; Christensen, M.H.; Li, R. Demonstration of heating demand peak shaving in smart homes. J. Phys. Conf. Ser. 2019, 1343, 012055. [CrossRef]

81. Cai, H.; Ziras, C.; You, S.; Li, R.; Honoré, K.; Bindner, H.W. Demand side management in urban district heating networks. Appl. Energy 2018, 230, 506-518. [CrossRef]

82. Foteinaki, K.; Li, R.; Pean, T.; Rode, C.; Salom, J. Evaluation of energy flexibility of low-energy residential buildings connected to district heating. Energy Build. 2020, 213, 109804. [CrossRef]

83. Andersen, P.V.K.; Georg, S.; Gram-Hanssen, K.; Heiselberg, P.K.; Horsbøl, A.; Johansen, K.; Johra, H.; Marszal-Pomianowska, A.; Møller, E.S. Using residential buildings to manage flexibility in the district heating network: Perspectives and future visions from sector professionals. IOP Conf. Ser. Earth Environ. Sci. 2019, 352, 012032. [CrossRef]

84. Luc, K.M.; Li, R.; Xu, L.; Nielsen, T.R.; Hensen, J.L. Energy flexibility potential of a small district connected to a district heating system. Energy Build. 2020, 225, 110074. [CrossRef]

85. Larsen, S.P.A.K.; Gram-Hanssen, K. When Space Heating Becomes Digitalized: Investigating Competencies for Controlling Smart Home Technology in the Energy-Efficient Home. Sustainability 2020, 12, 6031. [CrossRef]

86. Van Oevelen, T.; Vanhoudt, D.; Johansson, C.; Smulders, E. Testing and performance evaluation of the STORM controller in two demonstration sites. Energy 2020, 197, 117177. [CrossRef]

87. Kensby, J.; Trüschel, A.; Dalenbäck, J.-O. Potential of residential buildings as thermal energy storage in district heating systemsResults from a pilot test. Appl. Energy 2015, 137, 773-781. [CrossRef]

88. Weiß, T. Energy Flexible Buildings-The impact of building design on energy flexibility. IOP Conf. Ser. Earth Environ. Sci. 2019, 323, 012009. [CrossRef]

89. Leal, S.; Basciotti, D.; Schmidt, R.-R. Deployment of a wireless monitoring system for indoor comfort assessment in a smart heat load-shifting context. In Proceedings of the IECON 2013-39th Annual Conference of the IEEE Industrial Electronics Society, Vienna, Austria, 10-13 November 2013; pp. 5710-5715.

90. Aoun, N.; Bavière, R.; Vallée, M.; Aurousseau, A.; Sandou, G. Modelling and flexible predictive control of buildings space-heating demand in district heating systems. Energy 2019, 188, 116042. [CrossRef]

91. Sweetnam, T.; Spataru, C.; Barrett, M.; Carter, E. Domestic demand-side response on district heating networks. Build. Res. Inf. 2018, 47, 330-343. [CrossRef]

92. Sun, Q.; Li, H.; Ma, Z.; Wang, C.; Campillo, J.; Zhang, Q.; Wallin, F.; Guo, J. A Comprehensive Review of Smart Energy Meters in Intelligent Energy Networks. IEEE Internet Things J. 2016, 3, 464-479. [CrossRef]

93. Guelpa, E.; Marincioni, L. Demand side management in district heating systems by innovative control. Energy 2019, 188, 116037. [CrossRef]

94. Mishra, A.; Jokisalo, J.; Kosonen, R.; Kinnunen, T.; Ekkerhaugen, M.; Ihasalo, H.; Martin, K. Demand response events in district heating: Results from field tests in a university building. Sustain. Cities Soc. 2019, 47, 101481. [CrossRef]

95. Claessens, B.J.; Vanhoudt, D.; Desmedt, J.; Ruelens, F. Model-free control of thermostatically controlled loads connected to a district heating network. Energy Build. 2018, 159, 1-10. [CrossRef]

96. Peltokorpi, A.; Talmar, M.; Castren, K.; Holmström, J. Designing an organizational system for economically sustainable demandside management in district heating and cooling. J. Clean. Prod. 2019, 219, 433-442. [CrossRef]

97. Larsen, S.P.; Johra, H. User engagement with smart home technology for enabling building energy flexibility in a district heating system. IOP Conf. Ser. Earth Environ. Sci. 2019, 352, 012002. [CrossRef] 
98. Lambert, R.; Kolb, S.; Leppä, L.; Tull, S. Large-scale implementation of peak heating power optimization and demandresponse in residential buildings connected to district heating systems. Eceee Summer Study Proc. 2019, 929-938. Available online: https:/ / www.eceee.org/library/conference_proceedings / eceee_Summer_Studies/2019/5-smart-and-sustainable-communities / large-scale-implementation-of-peak-heating-power-optimization-and-demand-response-in-residential-buildings-connected-todi strict-heating-systems / (accessed on 18 December 2020).

99. Li, H.; Sun, Q.; Zhang, Q.; Wallin, F. A review of the pricing mechanisms for district heating systems. Renew. Sustain. Energy Rev. 2015, 42, 56-65. [CrossRef]

100. Song, J.; Wallin, F.; Li, H. District heating cost fluctuation caused by price model shift. Appl. Energy 2017, 194, 715-724. [CrossRef]

101. Hedegaard, R.E.; Kristensen, M.H.; Pedersen, T.H.; Brun, A.; Petersen, S. Bottom-up modelling methodology for urban-scale analysis of residential space heating demand response. Appl. Energy 2019, 242, 181-204. [CrossRef]

102. Arteconi, A.; Hewitt, N.; Polonara, F. State of the art of thermal storage for demand-side management. Appl. Energy 2012, 93, 371-389. [CrossRef]

103. Zhang, H.; Baeyens, J.; Cáceres, G.; Degrève, J.; Lv, Y. Thermal energy storage: Recent developments and practical aspects. Prog. Energy Combust. Sci. 2016, 53, 1-40. [CrossRef]

104. Alva, G.; Lin, Y.; Fang, G. An overview of thermal energy storage systems. Energy 2018, 144, 341-378. [CrossRef]

105. Réveillère, A.; Hamm, V.; Lesueur, H.; Cordier, E.; Goblet, P. Geothermal contribution to the energy mix of a heating network when using Aquifer Thermal Energy Storage: Modeling and application to the Paris basin. Geothermics 2013, 47, 69-79. [CrossRef]

106. Guo, X.; Goumba, A.P.; Wang, C. Comparison of Direct and Indirect Active Thermal Energy Storage Strategies for Large-Scale Solar Heating Systems. Energies 2019, 12, 1948. [CrossRef]

107. Carpaneto, E.; Lazzeroni, P.; Repetto, M. Optimal integration of solar energy in a district heating network. Renew. Energy 2015, 75, 714-721. [CrossRef]

108. Xu, J.; Wang, R.; Li, Y. A review of available technologies for seasonal thermal energy storage. Sol. Energy 2014, 103, 610-638. [CrossRef]

109. Tulus, V.; Boer, D.; Cabeza, L.F.; Jiménez, L.; Guillén-Gosálbez, G. Enhanced thermal energy supply via central solar heating plants with seasonal storage: A multi-objective optimization approach. Appl. Energy 2016, 181, 549-561. [CrossRef]

110. Van Der Heijde, B.; Vandermeulen, A.; Salenbien, R.; Helsen, L. Representative days selection for district energy system optimisation: A solar district heating system with seasonal storage. Appl. Energy 2019, 248, 79-94. [CrossRef]

111. Hirvonen, J.; Rehman, H.U.; Sirén, K. Techno-economic optimization and analysis of a high latitude solar district heating system with seasonal storage, considering different community sizes. Sol. Energy 2018, 162, 472-488. [CrossRef]

112. Köfinger, M.; Schmidt, R.; Basciotti, D.; Terreros, O.; Baldvinsson, I.; Mayrhofer, J.; Moser, S.; Tichler, R.; Pauli, H. Simulation based evaluation of large scale waste heat utilization in urban district heating networks: Optimized integration and operation of a seasonal storage. Energy 2018, 159, 1161-1174. [CrossRef]

113. Moser, S.; Mayrhofer, J.; Schmidt, R.; Tichler, R. Socioeconomic cost-benefit-analysis of seasonal heat storages in district heating systems with industrial waste heat integration. Energy 2018, 160, 868-874. [CrossRef]

114. Chambers, J.; Zuberi, S.; Zuberi, M.J.S.; Narula, K.; Patel, M.K. Spatiotemporal analysis of industrial excess heat supply for district heat networks in Switzerland. Energy 2020, 192, 116705. [CrossRef]

115. Guelpa, E.; Verda, V. Thermal energy storage in district heating and cooling systems: A review. Appl. Energy 2019, 252, 113474 [CrossRef]

116. Rohde, D.; Andresen, T.; Nord, N. Analysis of an integrated heating and cooling system for a building complex with focus on long-term thermal storage. Appl. Therm. Eng. 2018, 145, 791-803. [CrossRef]

117. Rohde, D.; Knudsen, B.R.; Andresen, T.; Nord, N. Dynamic optimization of control setpoints for an integrated heating and cooling system with thermal energy storages. Energy 2020, 193, 116771. [CrossRef]

118. Haeseldonckx, D.; Peeters, L.; Helsen, L.; D'Haeseleer, W. The impact of thermal storage on the operational behaviour of residential CHP facilities and the overall $\mathrm{CO}_{2}$ emissions. Renew. Sustain. Energy Rev. 2007, 11, 1227-1243. [CrossRef]

119. Fragaki, A.; Andersen, A.N.; Toke, D. Exploration of economical sizing of gas engine and thermal store for combined heat and power plants in the UK. Energy 2008, 33, 1659-1670. [CrossRef]

120. Pagliarini, G.; Rainieri, S. Modeling of a thermal energy storage system coupled with combined heat and power generation for the heating requirements of a University Campus. Appl. Therm. Eng. 2010, 30, 1255-1261. [CrossRef]

121. McDaniel, B.; Kosanovic, D. Modeling of combined heat and power plant performance with seasonal thermal energy storage. J. Energy Storage 2016, 7, 13-23. [CrossRef]

122. Sartor, K.; Dewallef, P. Integration of heat storage system into district heating networks fed by a biomass CHP plant. J. Energy Storage 2018, 15, 350-358. [CrossRef]

123. Nuytten, T.; Claessens, B.; Paredis, K.; Van Bael, J.; Six, D. Flexibility of a combined heat and power system with thermal energy storage for district heating. Appl. Energy 2013, 104, 583-591. [CrossRef]

124. Romanchenko, D.; Kensby, J.; Odenberger, M.; Johnsson, F. Thermal energy storage in district heating: Centralised storage vs. storage in thermal inertia of buildings. Energy Convers. Manag. 2018, 162, 26-38. [CrossRef]

125. Hennessy, J.; Li, H.; Wallin, F.; Thorin, E. Flexibility in thermal grids: A review of short-term storage in district heating distribution networks. Energy Procedia 2019, 158, 2430-2434. [CrossRef]

126. Shinkai, K.; Kasuya, A.; Kato, M. Performance evaluation of floor thermal storage system. ASHRAE Transact. $2000,106$. 
127. Heier, J.; Bales, C.; Martin, V. Combining thermal energy storage with buildings-A review. Renew. Sustain. Energy Rev. 2015, 42, 1305-1325. [CrossRef]

128. Sun, Y.; Wang, S.; Xiao, F.; Gao, D. Peak load shifting control using different cold thermal energy storage facilities in commercial buildings: A review. Energy Convers. Manag. 2013, 71, 101-114. [CrossRef]

129. Vandermeulen, A.; Van Der Heijde, B.; Helsen, L. Controlling district heating and cooling networks to unlock flexibility: A review. Energy 2018, 151, 103-115. [CrossRef]

130. Li, Z.; Wu, W.; Shahidehpour, M.; Wang, J.; Zhang, B. Combined Heat and Power Dispatch Considering Pipeline Energy Storage of District Heating Network. IEEE Trans. Sustain. Energy 2016, 7, 12-22. [CrossRef]

131. Basciotti, D.; Judex, F.; Pol, O.; Schmidt, R.-R. Sensible heat storage in district heating networks: A novel control strategy using the network as storage. In Proceedings of the International Renewable Energy Storage Conference and Exhibition, Berlin, Germany, 28-30 November 2011.

132. Leśko, M.; Bujalski, W. Modeling of District Heating Networks for the Purpose of Operational Optimization with Thermal Energy Storage. Arch. Thermodyn. 2017, 38, 139-163. [CrossRef]

133. Vivian, J.; Quaggiotto, D.; Zarrella, A. Increasing the energy flexibility of existing district heating networks through flow rate variations. Appl. Energy 2020, 275, 115411. [CrossRef]

134. Li, P.; Wang, H.; Lv, Q.; Li, W. Combined Heat and Power Dispatch Considering Heat Storage of Both Buildings and Pipelines in District Heating System for Wind Power Integration. Energies 2017, 10, 893. [CrossRef]

135. Göransson, L.; Johnsson, F. A comparison of variation management strategies for wind power integration in different electricity system contexts. Wind Energy 2018, 21, 837-854. [CrossRef]

136. Palensky, P.; Dietrich, D. Demand Side Management: Demand Response, Intelligent Energy Systems, and Smart Loads. IEEE Trans. Ind. Inform. 2011, 7, 381-388. [CrossRef]

137. Lampropoulos, I.; Kling, W.L.; Ribeiro, P.F.; Berg, J.V.D. History of demand side management and classification of demand response control schemes. In Proceedings of the 2013 IEEE Power \& Energy Society General Meeting, Vancouver, BC, Canada, 21-25 July 2013.

138. Benetti, G.; Caprino, D.; Della Vedova, M.L.; Facchinetti, T. Electric load management approaches for peak load reduction: A systematic literature review and state of the art. Sustain. Cities Soc. 2016, 20, 124-141. [CrossRef]

139. Nordenstam, L.; Ilic, D.D.; Ödlund, L. Corporate greenhouse gas inventories, guarantees of origin and combined heat and power production-Analysis of impacts on total carbon dioxide emissions. J. Clean. Prod. 2018, 186, 203-214. [CrossRef]

140. Gu, C.; Liu, L.; Zhang, T.; Zheng, Y. Demand response model and impact studies based on bidirectional interactive of information and electrical energy. In Proceedings of the 2012 China International Conference on Electricity Distribution, Shanghai, China, 10-14 September 2012; pp. 1-6.

141. Zhang, Q.; Li, J. Demand response in electricity markets: A review. In Proceedings of the 20129 th International Conference on the European Energy Market, Florence, Italy, 10-12 May 2012; pp. 1-8.

142. Ahmad, A.; Javaid, N.; Qasim, U.; Khan, Z.A. Demand Response: From Classification to Optimization Techniques in Smart Grid. In Proceedings of the 2015 IEEE 29th International Conference on Advanced Information Networking and Applications Workshops, Gwangiu, Korea, 24-27 March 2015; pp. 229-235.

143. Eid, C.; Codani, P.; Perez, Y.; Reneses, J.; Hakvoort, R. Managing electric flexibility from Distributed Energy Resources: A review of incentives for market design. Renew. Sustain. Energy Rev. 2016, 64, 237-247. [CrossRef]

144. Heussen, K.; You, S.; Biegel, B.; Hansen, L.H.; Andersen, K.B. Indirect control for demand side management-A conceptual introduction. In Proceedings of the 2012 3rd IEEE PES Innovative Smart Grid Technologies Europe (ISGT Europe), Berlin, Germany, 14-17 October 2012; pp. 1-8.

145. Le Ray, G.; Larsen, E.M.; Pinson, P. Evaluating price-based demand response in practice—With application to the EcoGrid EU Experiment. IEEE Trans. Smart Grid 2016, 9, 2304-2313. [CrossRef] 